University of Nebraska - Lincoln

DigitalCommons@University of Nebraska - Lincoln

Agronomy \& Horticulture -- Faculty Publications

Agronomy and Horticulture Department

$1-1944$

\title{
Effects of Drought, Dust, and Intensity of Grazing on Cover and Yield of Short-Grass Pastures
}

\author{
F. W. Albertson \\ Fort Hays Kansas State College \\ J. E. Weaver \\ University of Nebraska-Lincoln
}

Follow this and additional works at: https://digitalcommons.unl.edu/agronomyfacpub

Part of the Plant Sciences Commons

Albertson, F. W. and Weaver, J. E., "Effects of Drought, Dust, and Intensity of Grazing on Cover and Yield of Short-Grass Pastures" (1944). Agronomy \& Horticulture -- Faculty Publications. 477.

https://digitalcommons.unl.edu/agronomyfacpub/477

This Article is brought to you for free and open access by the Agronomy and Horticulture Department at DigitalCommons@University of Nebraska - Lincoln. It has been accepted for inclusion in Agronomy \& Horticulture -Faculty Publications by an authorized administrator of DigitalCommons@University of Nebraska - Lincoln. 


\section{ECOLOGICAL MONOGRAPHS}

\begin{tabular}{llc}
\hline \hline Volume 14 & JANUARY, 1944 & Number 1 \\
\hline \hline
\end{tabular}

\section{EFFECTS OF DROUGHT, DUST, AND INTENSITY OF GRAZING ON COVER AND YIELD OF SHORT-GRASS PASTURES ${ }^{1}$}

F. W. Albertson

Fort Hays Kansas State College

and

J. E. Weaver

University of Nebraska 


\section{TABLE OF CONTENTS}

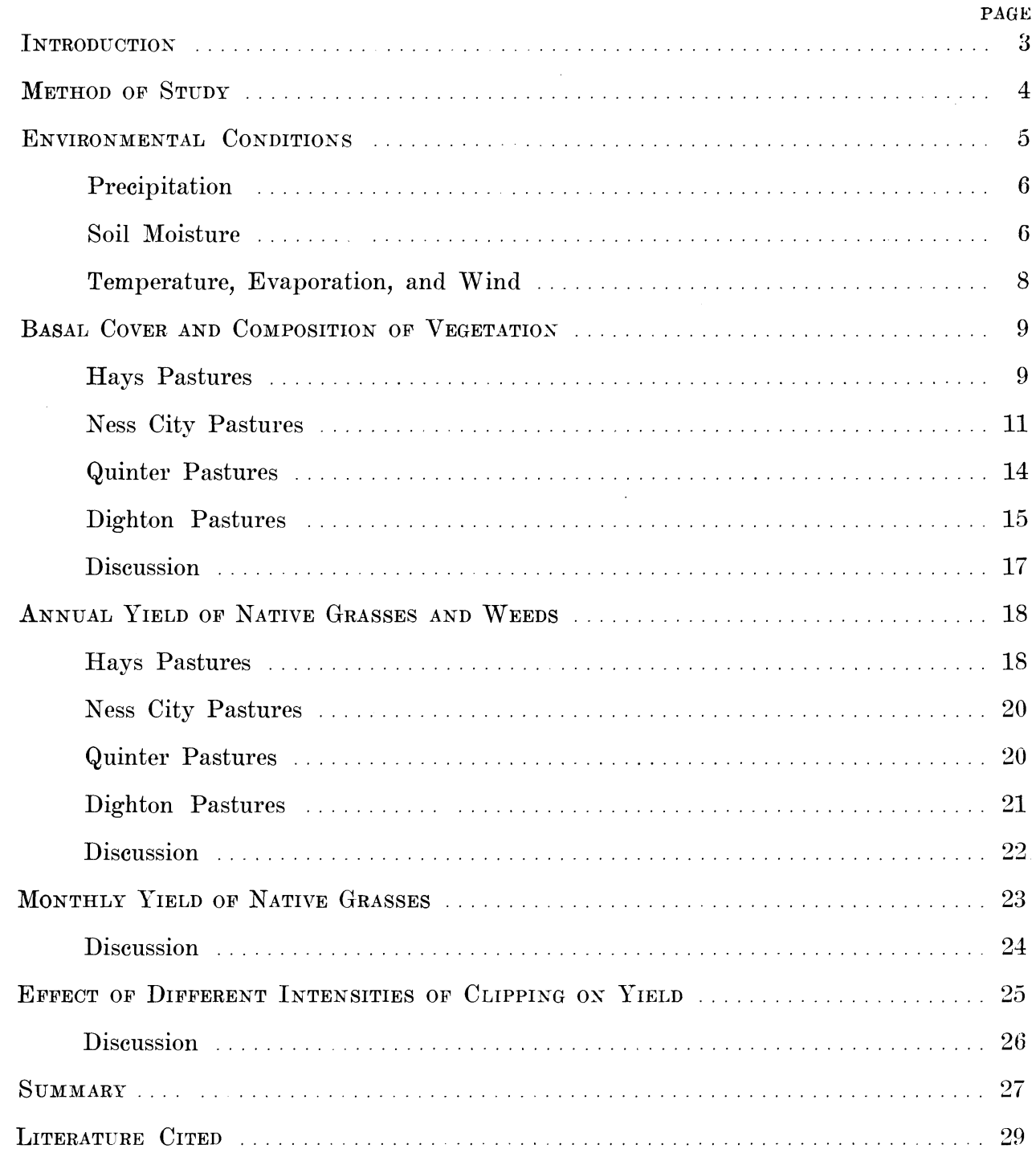




\section{EFFECTS OF DROUGHT, DUST, AND INTENSITY OF GRAZING ON COVER AND YIELD OF SHORT-GRASS PASTURES}

\section{INTRODUCTION}

The vast range lands of western Kansas occupy approximately one half of that area. They are now recovering from the terrible destruction wrought by overgrazing, drought, and dust-burial during the past decade. Since grass is man's most powerful ally in soil and water conservation, since pastures are tremendously important as the cheapest and most satisfactory feed for cattle, and since the recovery of the western range is not only an economic problem of great importance but a phenomenon of outstanding ecological interest, the redevelopment of the plant cover warrants careful investigation.

The pastures of western Kansas occupy a diversified topography and vary considerably in composition of vegetation. Those on the eastern edge of the area are a part of the mixed prairie association in which certain postclimax tall grasses extend westward in long arms and occupy the more moist soil, especially in ravines, and often intermix with mid grasses on steep hillsides, frequently where the soil is shallow and rocks outcrop. The short-grass disclimax, resulting from long continued grazing of the mixed prairie, occupies the level and gently rolling lands and extends westward over a vast area with decreasing precipitation. Since this blue grama (Bouteloua gracilis)-buffalo grass (Buchloe dactyloides) type is of the greatest extent and importance, it has received major consideration in this investigation. The pastures vary in size from 20 to 40 acres on farms where cultivated land is extensive to several thousand acres on rough land where growing cultivated crops is only incidental to livestock production. In many localities the income from the farm is almost entirely dependent upon livestock (Fig. 1).

An understanding of present conditions can be had only by a knowledge of past treatment of the

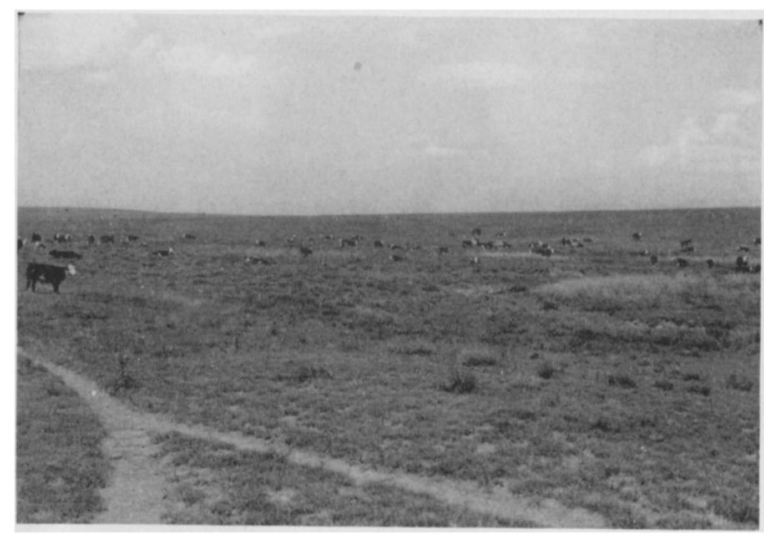

Fig. 1. Range land typical of western Kansas where the short grass furnishes most of the forage for livestock. August, 1942. ranges. High wind movement was common throughout the drought period and especially severe during the spring of 1935. Soil which was pulverized by excessive cultivation was carried as dust in large quantities from cultivated fields and deposited in layers or drifts on the drought-stricken prairie plants (Fig. 2). The cover of native vegetation was thus greatly reduced, in fact, the grasses were almost or completely annihilated over vast areas of range land.

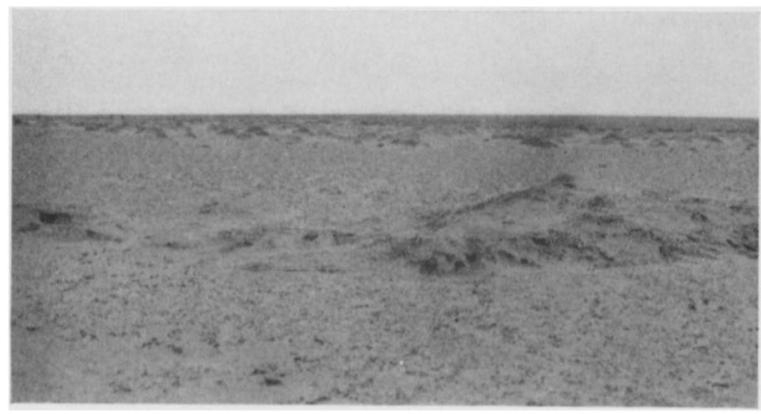

Fif. 2. Surface soil carried by wind from adjacent cultivated land and deposited in layers and drifts on a sparse, weakened vegetation. Lakin, Kan. July, 1939.

Planted crops failed to grow because of deficient moisture. This compelled the rancher to increase the usual length of the grazing season as well as the intensity of range utilization. This extreme overgrazing was responsible for further decline in the amount of original plant cover. The soil when devoid of native vegetation was often populated by numerous weedy annuals (Fig. 3 ). As a result, many farmers were confronted with the problem of increased losses in livestock due to the poisoning effect of various noxious weeds.

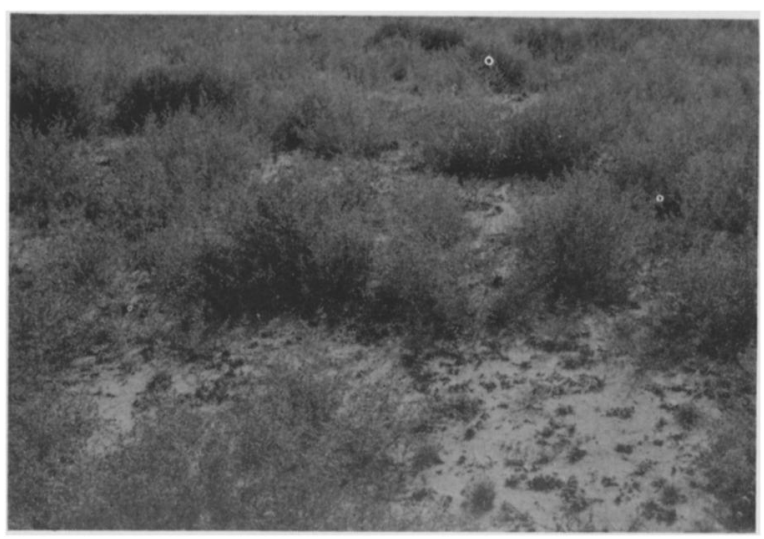

Fig. 3. Large Russian thistles forming a new cover on the drought-swept prairie. Usually the dead crowns of native grasses (foreground) furnished the only evidence that the area was once clothed with a dense cover of short grasses. This is typical of hundreds of ranges in western Kansas. Photo August, 1939. 
The prairie soil was bared by adverse environmental conditions and became extremely susceptible to wind erosion. It was the source of dust for further great storms which greatly damaged the ranges. When pastures were placed under the stress of these unfavorable environmental conditions it became evident that in those where good management had been practiced the original plant population suffered far less than where overgrazing or overgrazing with intense dusting had occurred. This investigation was init ated to determine the effect of drought, different intensities of grazing, and degrees of dusting from adjacent cultivated fields upon the basal cover and vield of the native vegetation.

\section{IIETHOD OF STUDY}

The plan of the investigation was to select a ser.es of pastures which had been detrimentally affected $b y$ past usage or environment in different degrees and to measure the nature and rate of recovery under protection. Increase in basal area, amount of the various species concerned, and dry we ght of forage produced were the chief criteria used in measuring recovery. This included, of course, a consideration of the environmental conditions of growth. Effects of different intensities of clipping were also asecrtained as well as the monthly yield.

Basal area gives a good picture of the structure of a type of vegetation. When used in perman nt quadrats, the increase or decrease in the abundance of individual species due to succession or different treaments can be followed accurately. Although the percentage results are not a sensitive mcasure of the change in yield, they definitely reflect any change in the nature of the plant cover (Savage 1937; Weaver $\&$ Albertson 1936). Dry weight of plants is one of the best quantitative characteristics of vegetation (Hanson 1938), and increase in dry weight is the best measure of growth (West, Briggs, \& Kidd 1920). Then basal area and dry weight are combined in a study of recovery of sod- and bunch-forming grasses a rather clear picture of development should be obtained.

The clip quadrat has been widely used by numerous American investigators in obta:n'ng vields (Sampson 1914; Sarvis 1923; Taylor \& Loftfield 1924; Canfield 1939; Hein \& Henson 1942; and others). Although clipping studies serve as a valuable supplement to grazing experiments, they differ in several respects from actual grazing. The chief differences have been pointed out by Culley, Campbell, and Canfield (1933) and Donald (1941). But despite these differences clip quadrats are invaluable and are widely used wherever quantitative ecological studies in grassland are pursued (West 1936).

Four pastures, representing various stages in range deterioration, were selected near each of four stations - Hays, Ness City, Quinter, and Dighton, Kansas. In addition, a prairie was selected near Phillipsburg, Kansas. Hays is in Ellis County and about 160 miles from the western state boundary. Phillipsburg lies 65 miles directly north of Hays and is in the northern tier of counties. Quinter is 50 miles west and north of Hays and Ness City and Dighton are 60 and 100 miles, respectively, southwest. All of these extensive ranges are in the mixed prairie association, and all but the prairie at Phillipsburg are portions of a great grazing disclimax. At Phillipsburg the vegetation has changed from mixed prairie to an open stand of short grass solely as a result of drought and coverage by dust.

The pastures at each station, except Phillipsburg, were of four different classes as follows:

Class 1. Lightly grazed and lightly dusted.

Class 2. Heavily grazed and lightly dusted.

Class 3. Lightly grazed but heavily dusted.

Class 4. Both heavily grazed and heavily dusted.

Intensity of grazing in the class 1 and 2 pastures at Hays had been about 1 animal unit for each 20 acres, and in other class 1 and 2 pastures about 1 animal unit for each 20 to 30 acres, although the use records at Quinter are incomplete. Class 3 pastures were similar to class 1 before the heavy dusting. Moreover, during years of poor productivity these pastures had been withheld from grazing. The heavily grazed class 2 and class 4 pastures had been stocked at the rate of 1 animal unit for each 8 to 12 acres, and grazing was more or less continuous regardless of precipitation.

The class 1 pasture at each station represented the best conditions found in that vic:nity. Grazing was light and frequently deferred until about August 1, a practice common among the best cattle producers even before the dry cycle. Drought damage under this type of utilization was reduced to a minimum. These pastures were commonly located at some distance from cultivated fields or if in close proximity to them judicious soil management had been practiced to prevent dust blowing. Thus, coverage by dust, locally known as dusting, was almost negligible (Fig. 4A). At Phillipsburg the vegetation was identical with that of a class 1 pasture.

Class 2 pastures were subjected to considerably heavier grazing than were those of the first class. Dusting, however, was usually scarcely more intense (Fig. 4B).

In class 3 pastures grazing was so light that it did not reduce the plant cover. Considerable damage, however, had resulted from dust blown from adjacent cultivated fields (Fig. 4C). This class is placed third since heavy dusting is even more injurious to short grass than heavy grazing.

Class 4 pastures were the poorest that could be found in each locality. Grazing and dusting had usually been so severe that little or none of the original vegetation remained (Fig. 4D).

Twenty meter quadrats, arranged in groups of four for convenience of examination, were staked out in each pasture and clipped annually (Fig. 5). Approximately 16 other similar quadrats in each exclosure were included in 1941 to secure data on the monthly yield in relation to intensity of grazing as simulated by frequent clipping. Livestock were ex- 


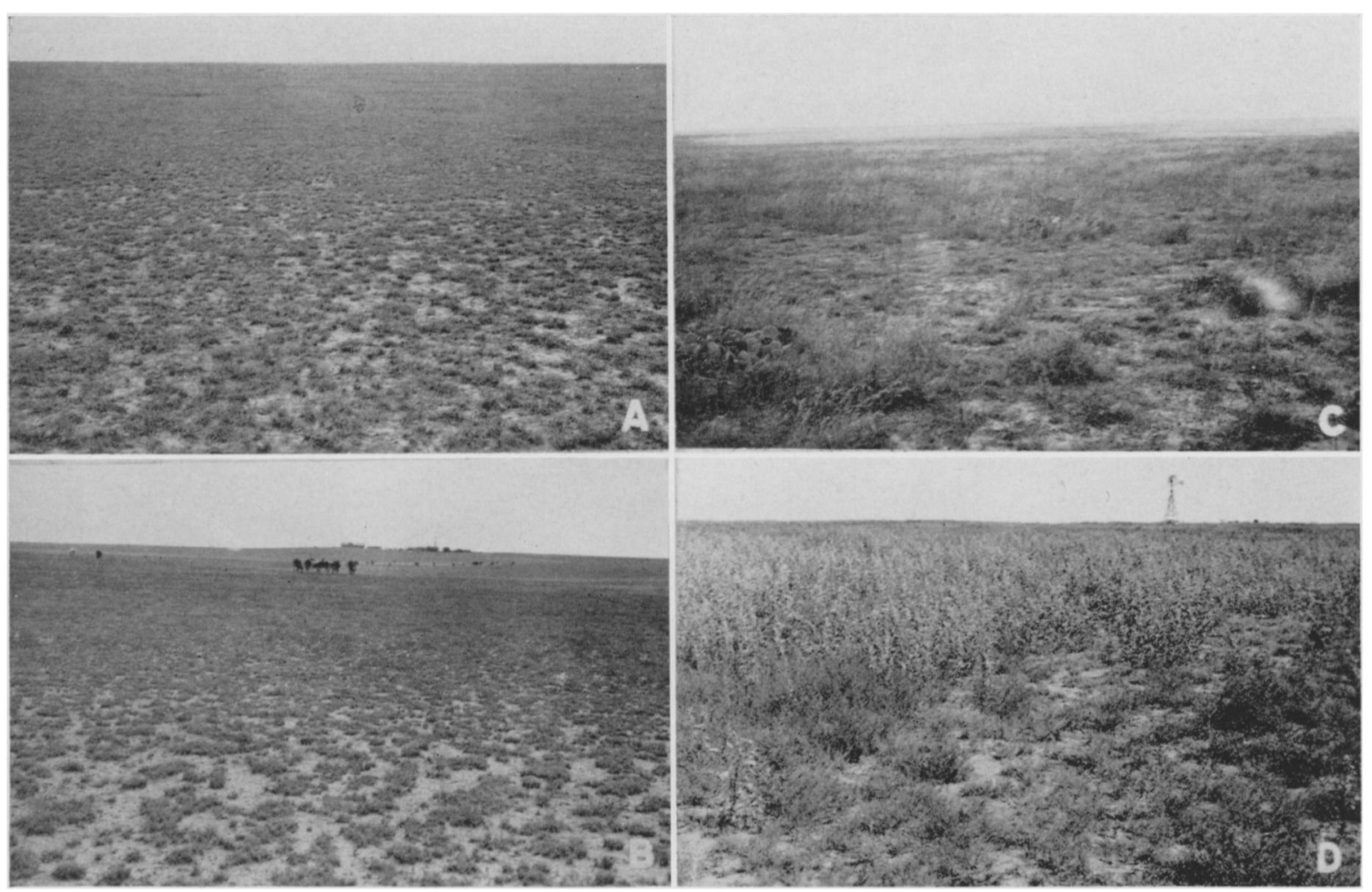

FIG. 4. A. Typical view of a class 1 pasture where the open cover remained intact throughout most of the drought. Dighton, Kan. September, 1940. B. A class 2 pasture with typical open cover. In early spring such ranges were usually infested with Lepidium densiflorum, Lappula occidentalis, and other annual weeds. August, 1940. C. View of a class 3 pasture near Ness City, Kan., where the original amount of cover and its composition had been greatly modified. Many weeds such as Salsola pestifer were scattered over the prairie. September, 1940. D. An overgrazed pasture heavily dusted in 1935, near Dighton. Most of the original cover died and has been replaced by Chenopodium album, Helianthus annuus, Amaranthus retroflexus, and other weeds. June, 1940.

cluded from these areas by means of barbed wire fences. All forage was clipped monthly to within one half inch of the surface of the soil except that harvested only at the end of the summer. The forage was separated into short grass, mid grass, native forbs, and weeds and placed in paper bags. It was air-dried and weighed to the nearest tenth gram. Yields, exclusive of native forbs, were expressed in pounds per acre. Native forbs were not included

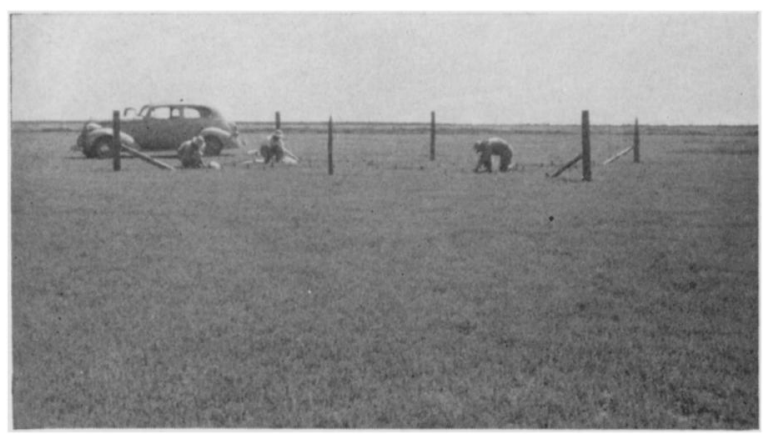

Fig. 5. View of an exclosure in class 1 pasture near Dighton. The corners of each quadrat were marked permanently with stakes. A thick growth of Lepidium densiflorum gives the appearance of a good stand of grass. since they were absent over 60 percent of the area and were inconsequential in the remainder.

The exclosures and the surrounding pastures were examined monthly. Approximately half of the quadrats were charted (that is, the basal area mapped at a height of one half inch) each fall by means of a pantograph. In charting, only places without cover of native perennial grasses and larger than .8 inch in diameter were considered bare. The percentage of basal cover for each species in each quadrat was obtained by use of a planimeter or by superimposing circles of known area inscribed on tracing paper upon those of the charted quadrat sheet.

Water content of soil was determined at regular intervals throughout the growing seasons of 1940 and 1941. Records of precipitation and temperature were secured from the United States Weather Bureau which has an observer at each of the stations.

\section{ENVIRONMENTAL CONDITIONS}

The climate of the mixed prairie region is characterized by great fluctuations in the amount and time of precipitation, temperature, humidity, and wind movement. There are often long periods during the growing season with little or no rainfall when 
temperature and wind movement are high and the relative humidity and available soil moisture extremely low. The years 1940 and 1941 immediately followed a seven-year period of the most intense drought ever recorded. The accumulated deficits in precipitation at the five stations varied from 24.4 inches at Quinter to 43.1 inches at Phillipsburg. During the drought, the annual precipitation at any of the five stations exceeded the normal only twice; the soil became exceedingly dry to a depth of five feet, and vegetation was greatly damaged (Weaver \& Albertson 1940; Albertson \& Weaver 1942).

\section{Precipitation}

Low precipitation in 1939 had a pronounced carryover effect upon the native vegetation and for that reason it as well as the precipitation during the experiment must be considered. Total annual precipitation at Phillipsburg in 1939 was nearly 10 inches below the normal of 23 inches. The next greatest deficit was 8.3 inches at $\mathrm{D}$ ighton. Precipitation deficits of 7.8, 7.0, and 5.0 inches, respectively, occurred at Hays, Ness City, and Qu inter. Precipitation during the growing season (except June and August at Hays and August at Quinter) was below normal and usually far below for all of the summer months at all of the stations. The season was especially unfavorable to growth because of the long period of drought in autumn. It was during this time that the vegetation acquired the bluish-gray cast common to the short grasses after their death.

Precipitation during 1940 was above normal at Ness City and approximately normal at Hays (Fig. 6 ). It was somewhat below normal at Quinter and Dighton, but about 6 inches below at Phillipsburg. This growing season showed much improvement over that of 1939 (Figs. 6 and 7). Precipitation exceeded the normal, however, only about one third of the time. Rainfall for April and June was below normal at all five stations. It was normal or above at all stations during August, but during the remaining three months it was above normal at some stations and below at others.

The year 1941 showed still greater improvement in amount and distribution of precipitation. Rainfall was above normal more than half the time from April to September. It was much above normal at all stations during April and June; June, in particular, was an unusually wet month, at most stations the rainfall was at least twice normal. For example, it was 8.7 inches at Phillipsburg and 10.7 at Quinter. The rainfall for the remaining four summer months was somewhat erratic. At some stations it was much above normal, at others considerably below. At Hays, for example, rainfall during May was about .5 inch below normal, while at Dighton it was more than twice normal. Such differences had a significant effect upon the amount of soil moisture and the yield of forage at the two stations.

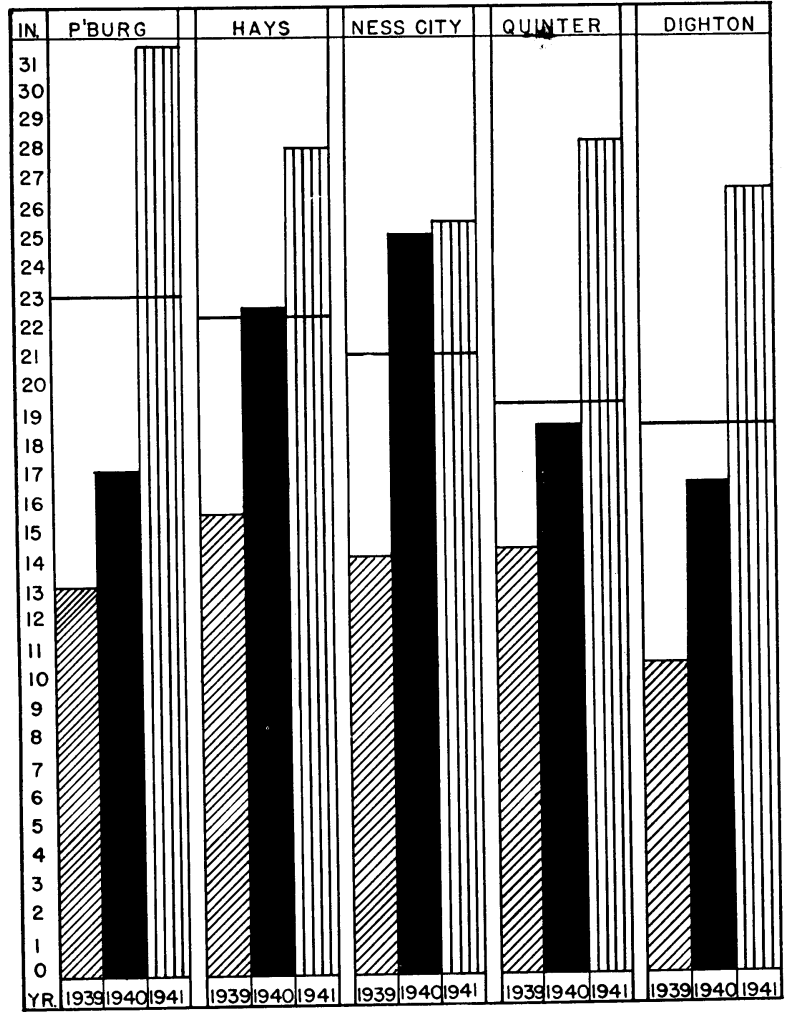

Fig. 6. Annual precipitation at the several stations. Normal precipitation is shown by the heavy horizontal lines.

\section{SoIL Moisture}

Determinations of water content of soil were made to a depth of 5 feet each month during the growing seasons of 1939, 1940, and 1941 at Phillipsburg, Hays, and Dighton. Total water content of soil minus the hygroscopic coefficient (which was determined for each soil depth at each station) is designated as water available for growth. The hygroseopic coefficients of these silt-loam or very fine sandy-loam soils ranged between 9.0 and 13.9 percent.

At Phillipsburg, the soil was mo:st to a depth of 2 feet in April, 1939, but this amount was soon reduced by vigorous absorption by the rapidly growing vegetation (Fig. 8). The 0.8 inch of rainfall during May was not enough to supply the demands for plant growth, and when soil samples were taken at the close of the month no moisture was available to a depth of 4 feet and less than 2 percent occurred in the fifth foot. Showers amounting to 3.6 inches during June but only 0.9 inch in July resulted in less than 5 percent available moisture in the surface foot and none below that depth. Moisture was further depleted dur.ng August. Continued drought during the fall resulted in the soil becoming so dry that much of the native vegetation died.

Winter snows and spring rains resulted in moist soil to a depth of a foot by April, 1940. This was soon exhausted and there was no available water on 


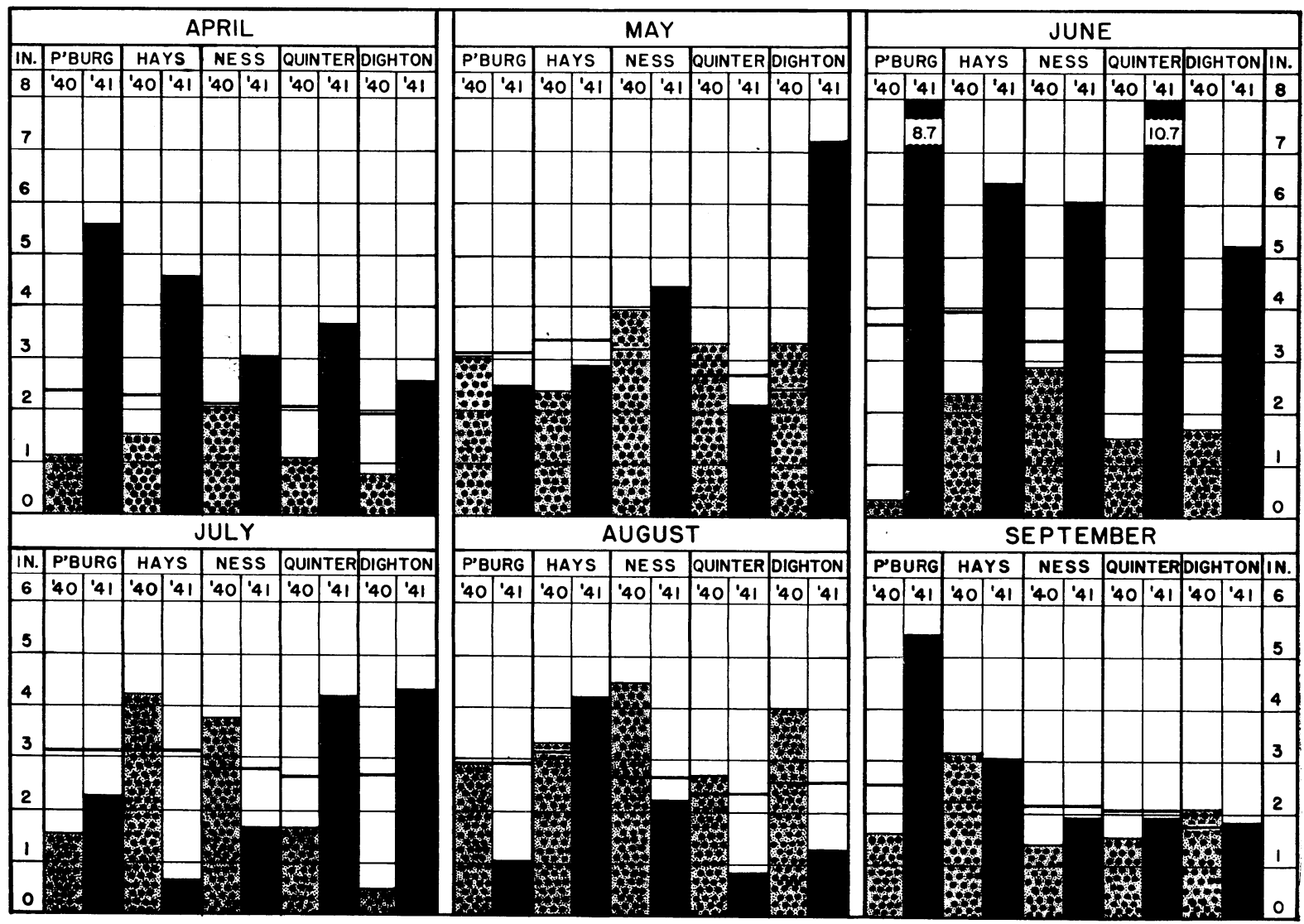

Fig. 7. Monthly precipitation (April to September inclusive) at each station in 1940 and 1941 . The heavy horizontal lines indicate normal rainfall

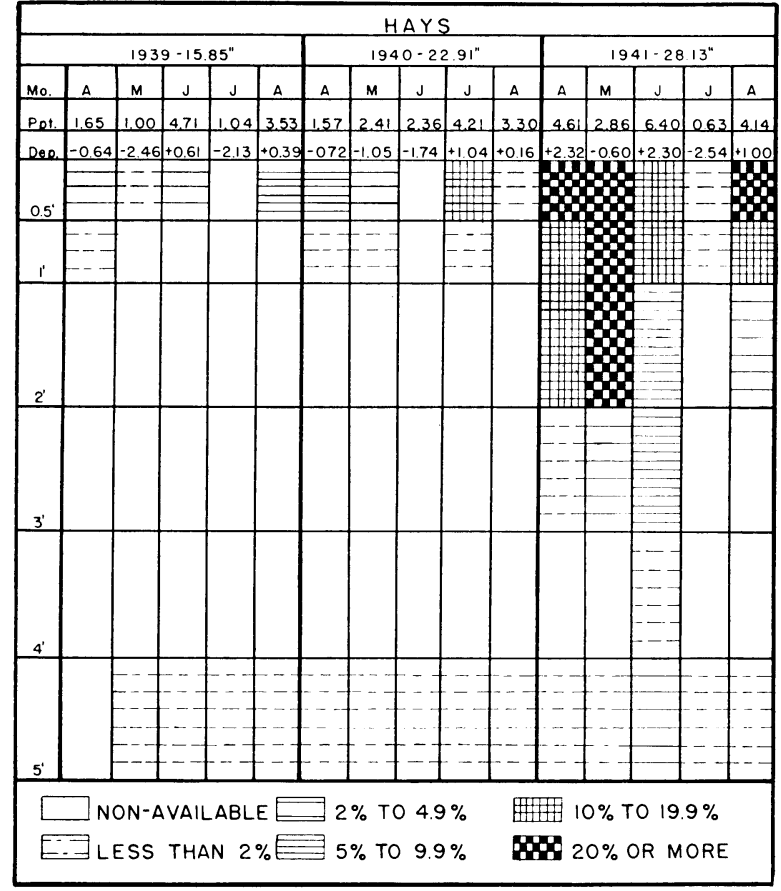

FIG. 8. Available soil moisture to a depth of 5 feet in ungrazed prairie at Phillipsburg. the dates of sampling during the remainder of the growing season. It is probable, however, that some moisture was available in the surface soil at intervals between the samplings.

In April, 1941, available moisture extended to a depth of 2 feet. Moist soil occurred to 4 feet on May 31, and by June 30 more than 20 percent moisture was available to a depth of 2 feet and from 5 to 15 to a depth of 5 feet. Moderate drought occurred in the upper soil during July but water was available below 12 inches. Abundant water for pant growth was found in the soil during August. The contrast of the favorable conditions of growth in 1941 to the extremely unfavorable ones in 1940 is very strik.ng.

At Hays, the soil was extremely dry in the spring of 1939 (Fig. 9). Water for growth was available only in the first foot. This was soon absorbed and by the end of May available moisture occurred on!y in the first 6 inches. A month later there was n:s mo.sture availab!e to a depth of four feet and less than 2 perecnt was present in the fifth foot. By the end of August more than 5 percent available water occurred in the upper 6 inches as a result of 3.5 inches of rain received during the month.

The precipitation, although normal in amount in 1940, was not sufficient to penetrate deeper than orre 


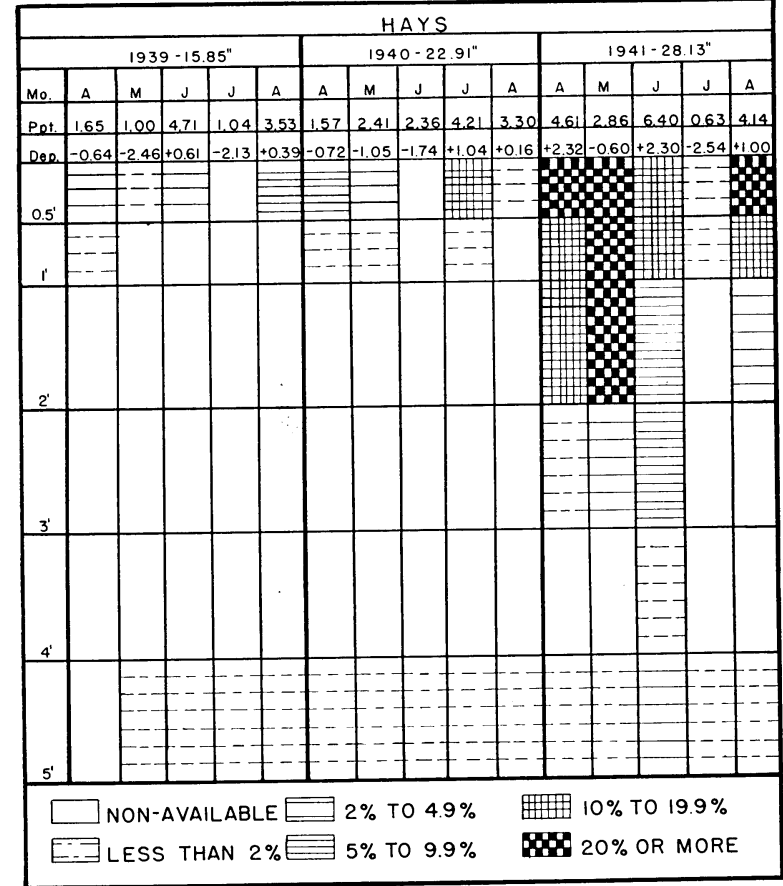

FIg. 9. Available soil moisture to a depth of 5 feet in the short-grass type at Hays.

foot, and the available soil moisture was less than 10 percent in April. It was less than 5 percent in May and there was none in June. Total rainfall of 4.2 inches in July resulted in more than 10 percent available moisture in the upper 6 inches, but less than 2 percent in the second six-inch layer. This moisture was quickly absorbed or evaporated and only a small amount was found in August.

Precipitation during the winter and early spring of 1941 greatly increased the moisture content in the first two feet of soil. The supply was further augmented in May when more than 20 percent available water occurred to a depth of 2 feet, and the third foot had nearly 5 percent. Water content in June was somewhat less than in May in the upper 3 feet, but for the first time since 1933 available soil mo:sture was present to a depth of 5 feet. The drought of July coupled with the rapid growth of vegetation reduced the amount of available moisture nearly to zero. During August, with rainfall of more than 4 inches, the amount of available water increased to about 20 percent in the first foot and to a smaller amount in the second.

At Dighton available soil moisture extended to a depth of only a foot in April, 1939 (Fig. 10). It increased during May, but was exhausted in the upper foot during June. The continuous drought resulted in no available moisture in July. Showers during August increased the available moisture content in the surface foot to nearly 10 percent.

Available moisture was found to extend to a depth of 2 feet in April, 1940. This was slightly reduced during succeeding weeks and only a small amount

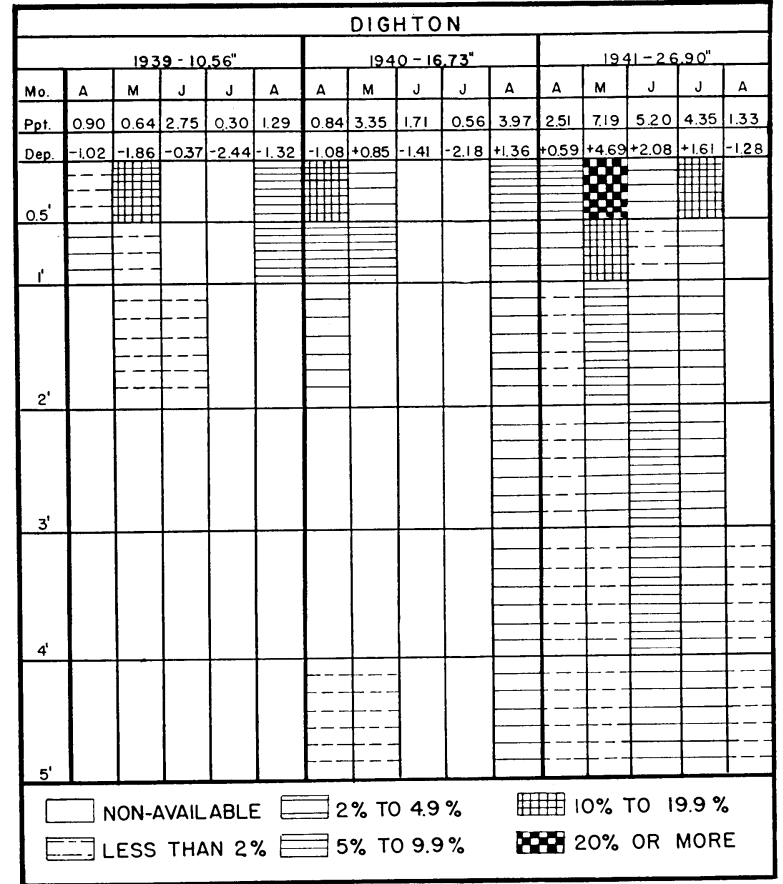

FIG. 10. Available soil moisture to a depth of 5 feet in the short-grass pasture at Dighton.

was available in May in the upper 6 inches but nearly 10 percent in the second six-inch level. No available water was present when samples were taken in June and July, 1940. This extreme drought caused the prairie vegetation to become completely dormant. August had a total rainfall of nearly 4 inches and available moisture was restored to a depth of 5 feet. ${ }^{2}$

The available soil moisture occurring in August was maintained with only a slight decrease during the winter of 1940-1941. Hence, when samples were taken in April water was found to be available, although in small amounts, to 5 feet. The well distributed rains of May totaled over 7 inches. This not only increased the amount of available soil moisture to more than 20 percent in the upper 6 inches but also replenished it to a depth of 3 feet. During June and July moisture was slightly less than in May, but it was always available to 5 feet in depth. The only drought of the season occurred during August when water became unavailable to 3 feet, with only a small amount available at greater depths.

\section{Temperature, Evaporation, and Wind}

Mean annual temperature for 1939 ranged from $2.8^{\circ}$ to $3.4^{\circ} \mathrm{F}$. above normal at the several stations. The greatest departure from the normal occurred at all stations during May, June, July, and September. For example, the temperature was $7.7^{\circ} \mathrm{F}$. above normal during May at Phillipsburg. Temperatures during the growing season of 1940 although usually above normal were lower than in 1939. During May,

${ }^{2}$ Cracks and fissures, often concealed at the surface, frequently occurred in the thoroughly dried soils and permitted places, but not generally. 
1941, the temperature ranged from $3.2^{\circ}$ to $4.8^{\circ} \mathrm{F}$. above normal at the five stations, but during June and July it was never more than slightly above and frequently below normal. During August and September the temperature was $1^{\circ}$ to $2^{\circ}$ above normal.

Total seasonal evaporation at Hays in inches from April to September, inclusive, was 60.7 in 1939, 49.2 in 1940, and 43.7 in 1941. Evaporation by months ranged from 5.8 to 13.6 inches the first year and was from 1 to 4 inches higher each month than during either of the two following summers. Evaporation in 1941 was lower during the early summer than in 1940 but that of August and September was somewhat higher. ${ }^{3}$

Wind movement at Hays from April to September, inclusive, was 39,985 miles in 1939 but only 36,621 the next year and 34,313 miles in 1941 . In 1939. wind movement ranged between 6,500 and 7,100 miles each month except August when there was less. Thus, it was much windier, hotter, and drier during 1939 than during either of the two following years. In all these respects 1941 was better suited to plant growth than 1940 .

\section{BASAL COVER AND COMPOSITION OF VEGETATION}

The mixed prairie of Kansas before and during the drought has been described (Weaver \& Albertson 1936; Albertson 1937, 1938, 1939, 1941; and Albertson \& Weaver 1942). The predrought average basal cover of the short grasses in 1932 varied between 80 and 95 percent. The extreme drought during the succeeding years greatly reduced the cover. The amount of decrease varied with the intensity of grazing and dusting. In places where judicious range management was practiced and where the pastures were naturally protected from dust blown from eultivated fields, reduction in cover was small. In other pastures, however, where the plants were weakened and coverage by dust was pronounced, the native plant population was reduced almost to zero. The cover and composition of the pastures studied at Hays, Ness City, Quinter, and Dighton follow in order. In the spring of 1940 each pasture was carefully examined before the quadrats were selected. They. were samples of areas which most nearly coincided with the average conditions in the particular pasture.

\section{Hays Pastures}

Class 1 pasture was given the best care possible during the drought, and the cover in the summer of 1939 was much above normal for ranges in that section of the state. Extended drought in the fall of 1939, however, caused a decrease in the amount of vegetation, and in the fall of 1940 the total cover of short grass was only 37 percent (Table 1). Of this amount, buffalo grass constituted 23 percent;

${ }^{3}$ Data on evaporation and wind movement were obtained from measurements made at Hays, Kansas, by Division of Dry Land Agriculture, Bur
ment of Agriculture.
TABLE 1. Percentage basal cover of each species of perennial grass in the different classes of pastures at each station, and total basal cover in 1940 and 1941.

\begin{tabular}{|c|c|c|c|c|c|c|c|c|}
\hline \multirow{2}{*}{$\begin{array}{c}\text { Location and } \\
\text { Class }\end{array}$} & \multicolumn{2}{|c|}{$\begin{array}{c}\text { Buffalo } \\
\text { Grass }\end{array}$} & \multicolumn{2}{|c|}{$\begin{array}{c}\text { Blue } \\
\text { Grama }\end{array}$} & \multicolumn{2}{|c|}{$\begin{array}{c}\text { Sand } \\
\text { Dropseed }\end{array}$} & \multicolumn{2}{|c|}{$\begin{array}{l}\text { Total } \\
\text { Cover }\end{array}$} \\
\hline & 1940 & 1941 & 1940 & 1941 & 1940 & 1941 & 1940 & 1941 \\
\hline Hays 1. & 23.0 & 86.5 & 14.0 & 7.6 & 0.0 & 0.0 & 37.0 & 94.1 \\
\hline Hays 2 . & 10.3 & 33.1 & 13.1 & 10.7 & 0.0 & 0.0 & 23.4 & 43.8 \\
\hline Hays 3 . & 0.1 & 0.0 & 9.3 & 33.9 & 0.6 & 6.8 & 10.0 & 40.7 \\
\hline Hays 4 . & 4.6 & 45.1 & 0.0 & 0.0 & 0.0 & 4.0 & 4.6 & 49.1 \\
\hline Ness City 1. & 4.2 & 28.3 & 14.4 & $15 . \dot{0}$ & 0.0 & 0.0 & 18.6 & 43.3 \\
\hline Ness City 2.. & 3.2 & 22.1 & 6.8 & 19.1 & 0.0 & 0.0 & 10.0 & 41.2 \\
\hline Ness City $3 \ldots$ & 8.3 & 38.3 & 4.3 & 12.1 & 00 & 0.0 & 12.6 & 50.4 \\
\hline Ness City $4 \ldots \ldots$ & 0.5 & 11.1 & 1.5 & 5.2 & 0.0 & 0.0 & 2.0 & 16.3 \\
\hline Quinter 1.. & 1.6 & 14.1 & 2.3 & 4.0 & 1.8 & 17.1 & 5.7 & 35.2 \\
\hline Quinter 2.. & 0.8 & 9.1 & 2.5 & 13.0 & 0.0 & 0.4 & 3.3 & 22.5 \\
\hline Quinter 3... & 7.9 & 27.1 & 1.9 & 7.4 & 0.0 & 0.0 & 9.8 & 34.5 \\
\hline Quinter $4 \ldots$ & 0.0 & 0.0 & 0.0 & 0.0 & 0.0 & 0.0 & 0.0 & 0.0 \\
\hline Dighton $1 \ldots$ & 4.6 & 43.5 & 6.0 & 11.0 & 0.0 & 0.0 & 10.6 & 54.5 \\
\hline Dighton 2 . & 15.4 & 74.7 & 3.8 & 3.1 & 0.0 & 0.0 & 19.2 & 77.8 \\
\hline Dighton 3 . & 15.1 & 46.6 & 5.9 & 4.0 & 0.0 & 0.8 & 21.0 & 51.4 \\
\hline Dighton 4 . & 0.0 & 0.0 & 2.2 & 3.4 & 0.0 & 0.0 & 2.2 & 3.4 \\
\hline
\end{tabular}

the remaining 14 percent consisted of blue grama. Where lack of soil moisture and not dusting was the cause of the decrease in cover, the individual bunches of grass were not killed but only reduced in size (Fig. 11A).

In pastures where drought and dusting were extreme, the cover of blue grama usually was greater than that of buffalo grass. In the better pastures, however, the reverse was frequently true. The continuous, fairly dense cover of short grass prevented any great amount of invasion of weedy annuals. In the spring of 1940, the class 1 range at Hays was sparsely populated with annuals, especially Hordeum pusillum, Lepidium densiflorum, and Lappula occidentalis. Nowhere, however, was this crop of weeds detrimental to the pasture grasses. The favorable growing conditions of 1941 were all that were needed to promote a good growth of buffalo grass. The cover of this short grass increased to 86.5 percent, while during the same period that of blue grama was reduced from 14 to 7.6 percent.

In class 2 pasture, the amount and composition of basal cover were similar before the drought to that of class 1. The reduction in 1940, or earlier, was considerably greater, however, due to adverse environmental conditions. The total cover of short grass in 1940 was only 23.4 percent and consisted mostly of small scattered tufts (Fig. 11B). In most locations the cover was rather evenly divided between the two dominants, but frequently a pure stand of one species took possession of areas varying from one to several square meters in extent. Here, as in class 1 pasture, the blue grama lost considerably during the growing season of 1941 . Conversely, buffalo grass made a great increase and had an average cover of 33.1 percent when charted in the fall. 

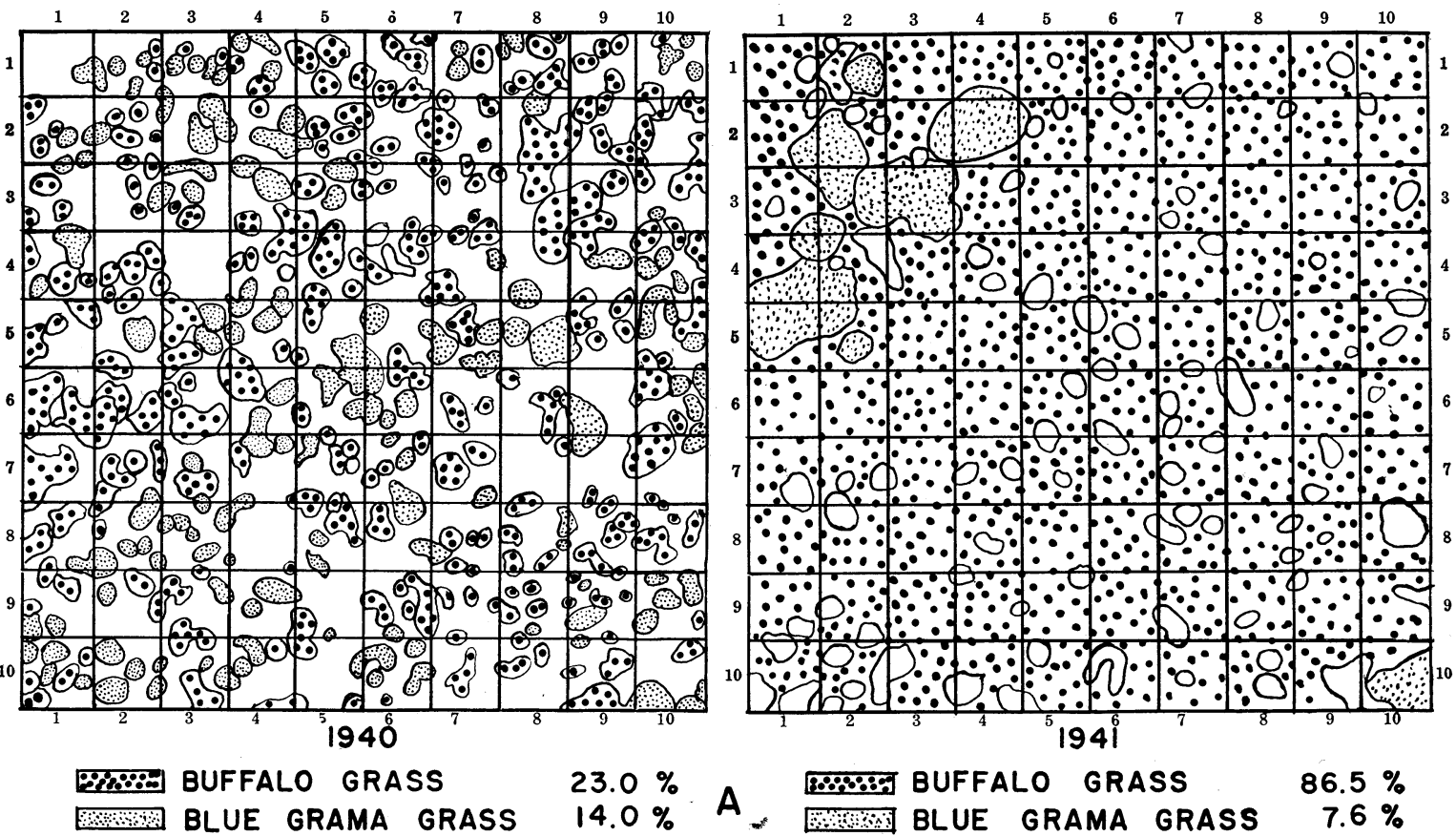

Fig. 11A. Typical meter quadrat showing basal cover of short grass in a class 1 pasture at Hays.

In class 3 pasture buffalo grass had nearly disappeared. Blue grama constituted only 9.3 percent and sand dropseed .6 percent. The basal cover and the composition varied so greatly in these dusted areas that it was difficult to select any quadrat that was representative of the area as a whole. The presence of sand dropseed was common to all quadrats, but in some either remnants of buffalo grass or small tufts of blue grama were present. The condition

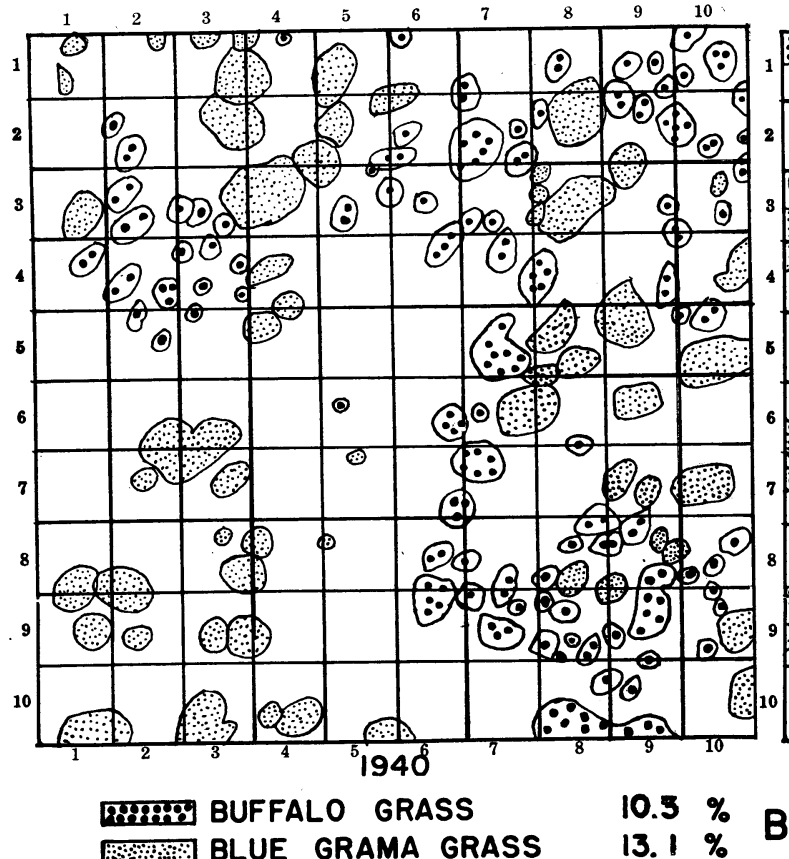

WI:D BLUE GRAMA GRASS

$13.1 \%$ where blue grama formed a greater cover than that of buffalo grass is typical for this area (Fig. 11C). The growth of blue grama during 1941 was phenomenal; its cover increased to 33.9 percent by fall. The number of tillers in each tuft increased manyfold and, as a consequence, the peripheral area occupied by each bunch was extended greatly. It seems that blue grama retained good vitality where it was not buried too deeply by dust, and when the rains came

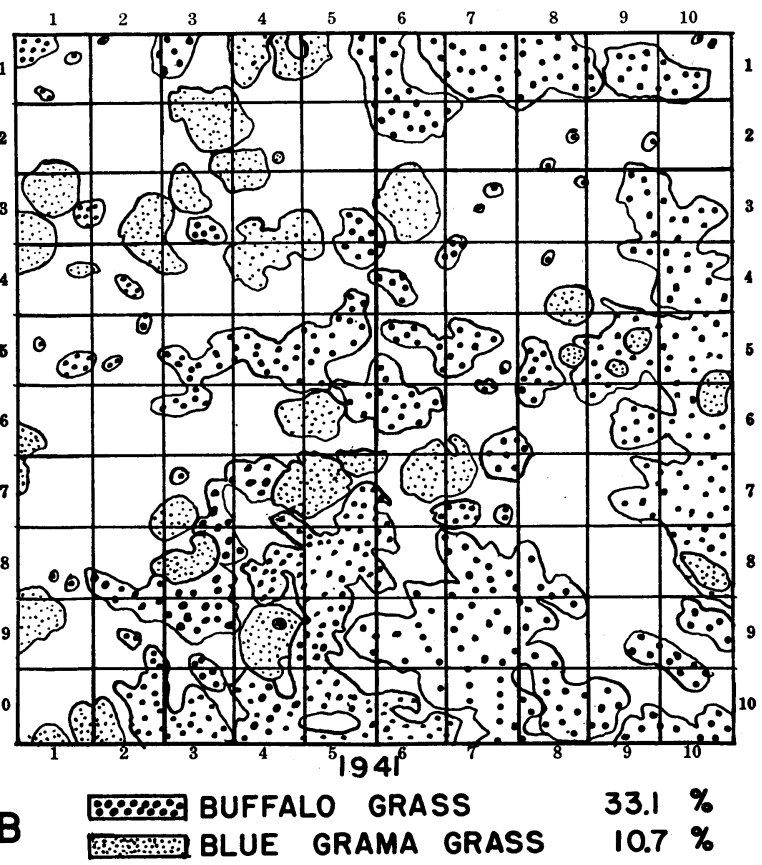

Fig. 11B. Meter quadrat showing open cover of short grass in a class 2 pasture at Hays. 

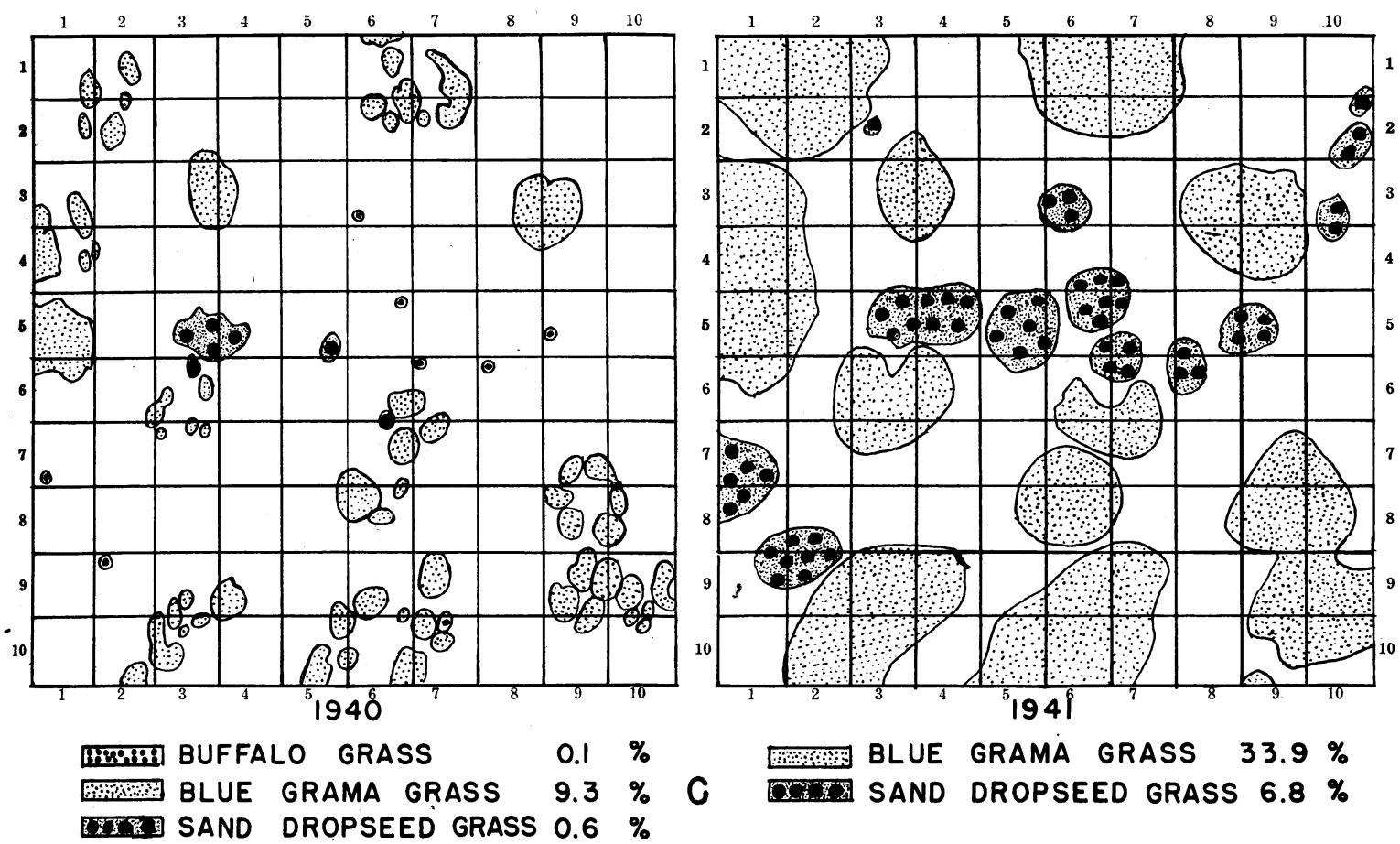

Fig. 11C. Open cover of blue grama and sand dropseed in a typical quadrat in a class 3 pasture at Hays.

to this rich soil it grew vigorously. This is quite in contrast to its losses in the other quadrats. Sand dropseed had also made fairly large gains and constituted 6.8 percent cover.

Class 4 pasture was located on rather low ground where both mid and tall grasses were formerly common. Due to intensive grazing, however, the composition of this area had gradually changed from that of mid and tall grasses to one of short grasses. The cover had been dense, perhaps 80 to 90 percent, until several years after the beginning of the drought in 1933. The storms of 1935 deposited a thick layer of fine dust over most of this entire area. In many places the native vegetation was completely smothered, in others only small remnants remained. The condition that prevailed in the fall of 1940, when the first charting was done, represented the cover not at its worst but after considerable improvement had taken place during the normal growing season of 1940. The cover of buffalo grass, however, was only 4.6 percent and no blue grama occurred. Seedlings of sand dropseed were present (Fig. 11D). The small scattered bunches of buffalo grass grew vigorously through the favorable season of 1941 and covered nearly half the soil when charted in the fall. Sand dropseed increased from a few seedlings to a cover of 4 percent.

The absence of blue grama and the presence of so small an amount of buffalo grass in 1940 resulted from heavy dusting and much overgrazing. Dusting in 1935 was so great that every vestige of native prairie vegetation was removed. Buffalo grass invaded these barren areas much more rapidly than did blue grama during the less severe drought years, such as 1938, and had made some growth during 1940 before it was charted in the fall. The rapid increase of basal cover from 4.6 percent the first year to 45.1 in 1941 is eloquent testimony of the recuperative powers of buffalo grass.

\section{Ness City Pastures}

Intensity of grazing of the pastures near Ness City was similar to that at Hays. The degree of dusting, however, was considerably more intense. Pastures not severely dusted during the period of drought, and particularly in 1935, were found only with great difficulty; in fact, the condition that prevailed was one where there was not only a rather continuous layer of dust to a depth of 1 to 3 inches but also great drifts extending in various directions across the range. The characteristic damage from such layers and drifts was the complete obliteration of all vegetation over comparatively large areas. It was not uncommon to find nearly level tracts, even 160 acres in extent, where no native vegetation remained except on sharp inclines where dust failed to accumulate.

Class 1 pasture at Ness City had been given the best treatment that could be found in the locality. Light grazing was common and deferred grazing had been practiced occasionally. Studies had been made in this pasture several years previous to 1939. The average cover in 1937 was about 5 percent. It consisted mostly of blue grama and buffalo grass. The favorable growing conditions during 1940 resulted in a considerable increase, and when charted in the fall a total basal area of $\mathbf{1 8 . 6}$ percent was found. It was composed of 4.2 percent buffalo grass and 14.4 blue 


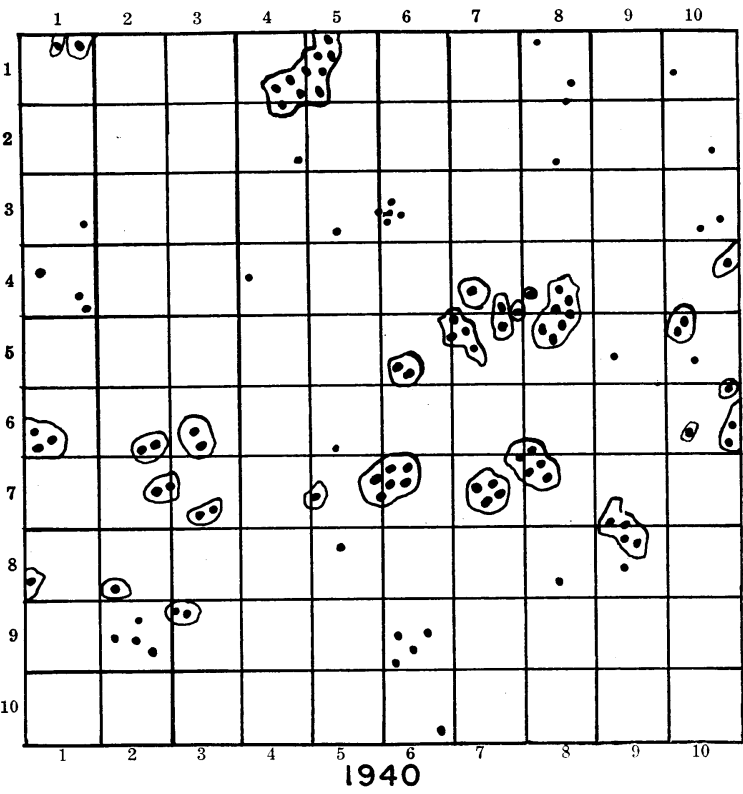

a.::9. BUFFALO GRASS $4.6 \%$
$\ldots . . . .$. SAND DROPSEED SEEDLINGS

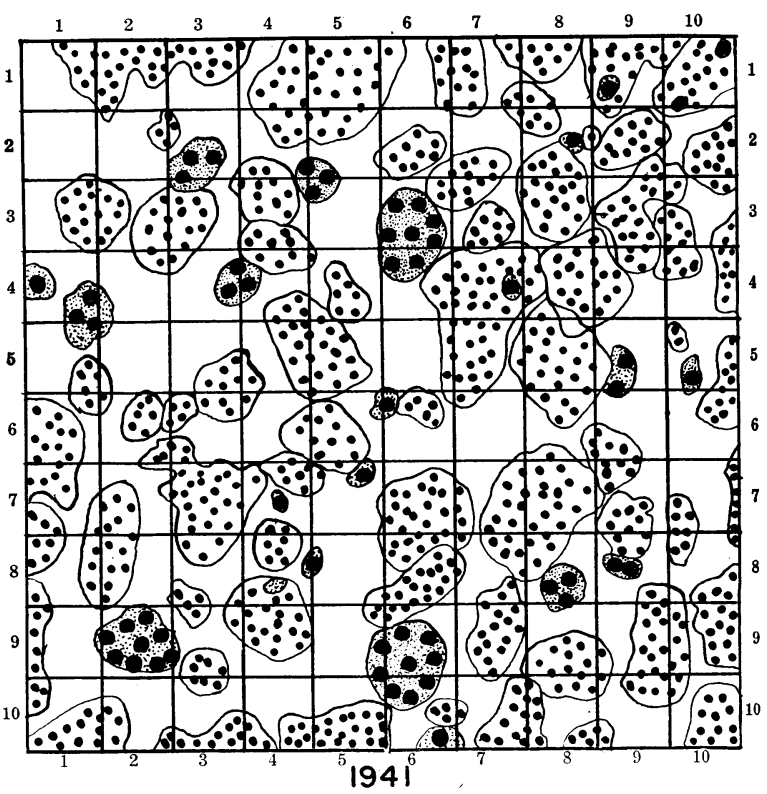

[G\%:요 BUFFLO GRASS $45.1 \%$

SAND DROPSEED GRASS $4.0 \%$

Fig. 11D. Quadrat at Hays where the short grass cover had been greatly reduced.

grama (Fig. 12A). In 1941 the amount of vegetation had increased to 43.3 percent, 28.3 being buffalo grass and 15.0 blue grama. The increases occurred mainly through the enlargement of small tufts of grass that were alive in the fall of 1940 . In many places, the spread of buffalo grass was very vigorous and greatly exceeded that of blue grama. In fact, when charted in the fall of 1941, some of the bunches of blue grama had disappeared.

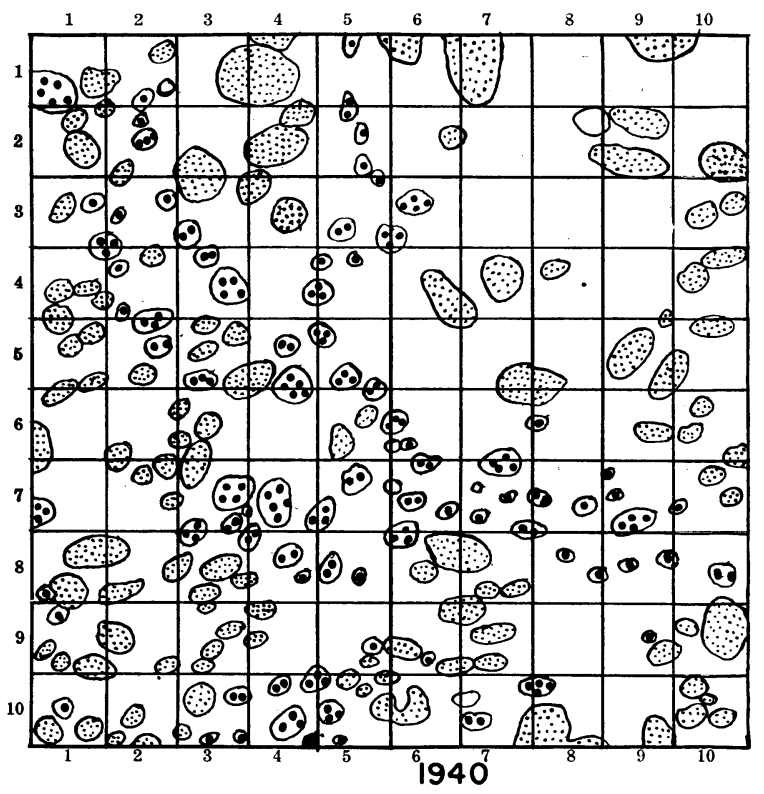

$\begin{array}{ll}\text { EFMA BUFFALO GRASS } & 4.2 \% \\ \text { BLUE GRAMA GRASS } & 14.4 \%\end{array}$
In 1940 , the cover in class 2 pasture was only 10 percent, about one third was buffalo grass and two thirds blue grama (Fig. 12B). The characteristic small, isolated tufts of grass prevailed. The increase during 1941 "was not equally shared by both short grasses, since buffalo grass increased sevenfold. Of the total cover of 41.2 percent, buffalo grass constituted 22.1 and blue grama 19.1 percent. Tufts of short grasses were less numerous in 1941 than in the

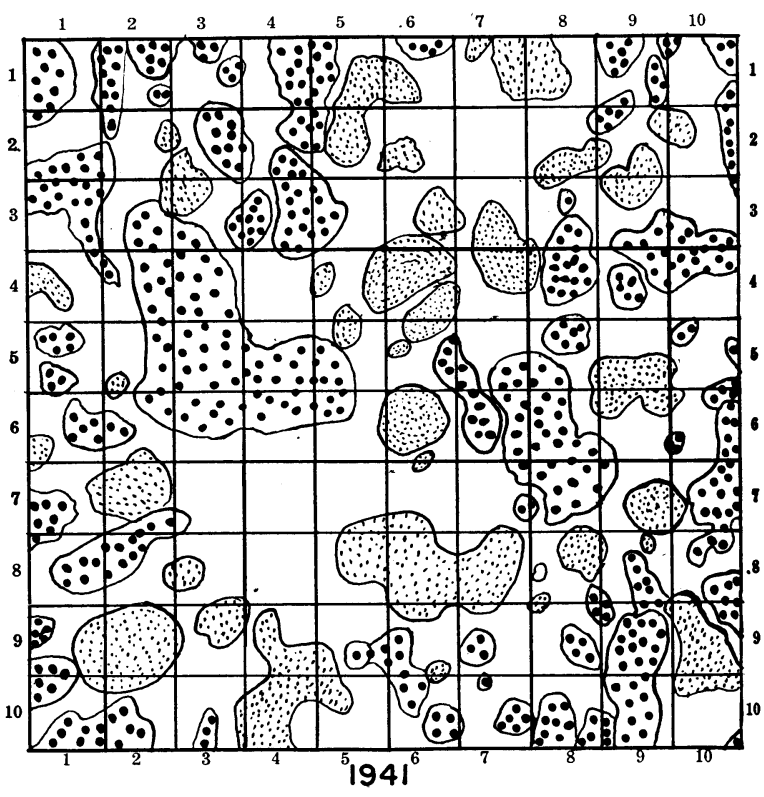

A

$28.3 \%$ Fig. 12A. Typical square meter in class 1 pasture at'Ness City. 

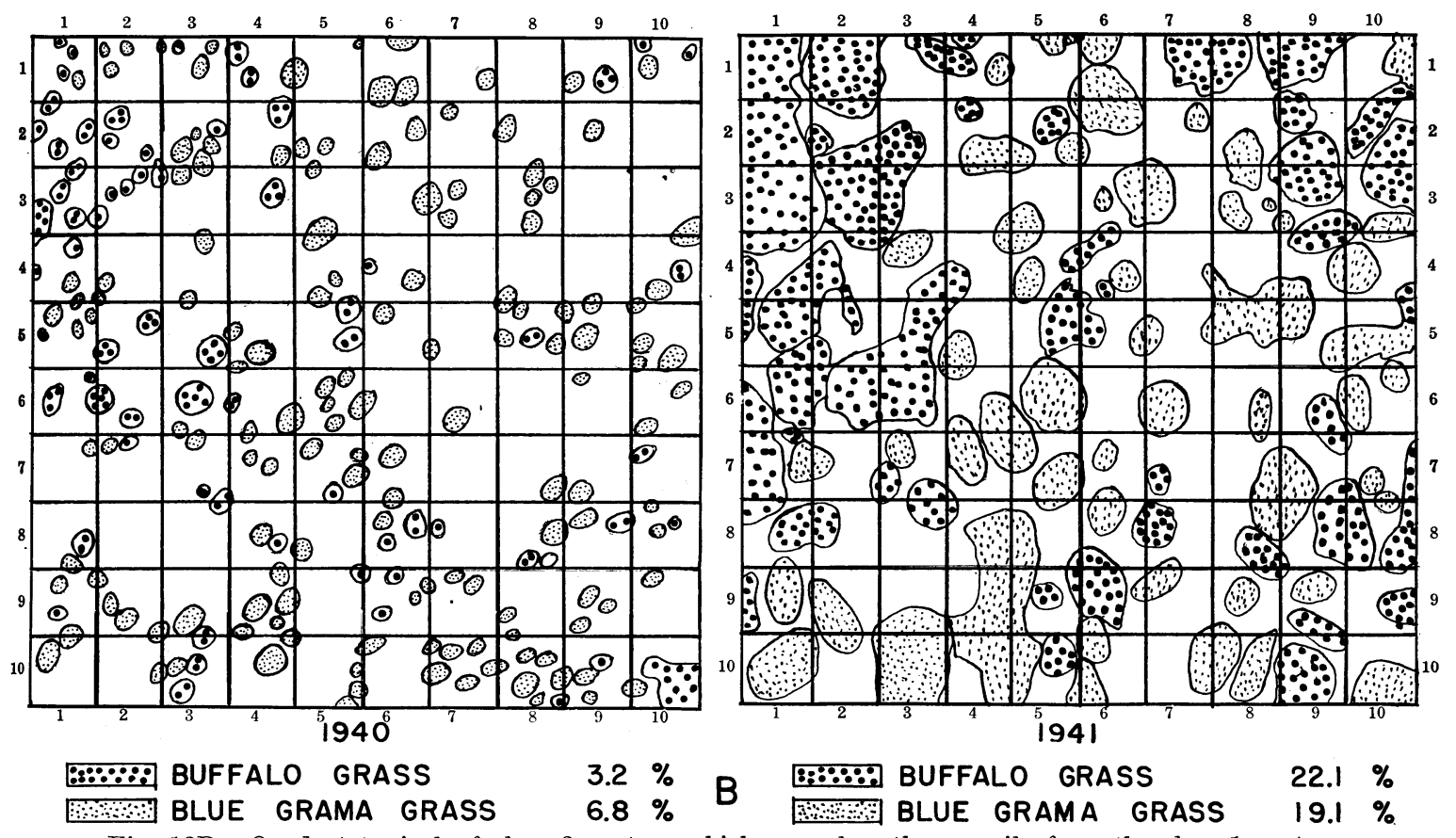

Fig. 12B. Quadrat typical of class 2 pasture which $w$ as less than a mile from the class 1 pasture.

previous year. This doubtless resulted from the merging of the smaller ones through growth.

Cover in class 3 pasture had been materially reduced during the dry years and especially in 1939 . In the fall of 1940 it was 12.6 percent; 8.3 percent was buffalo grass and only 4.3 blue grama (Fig. 12C). In 1941 the cover of buffalo grass had in. creased to 38.3 percent but that of blue grama only to 12.1, making a total basal cover of 50.4 percent.

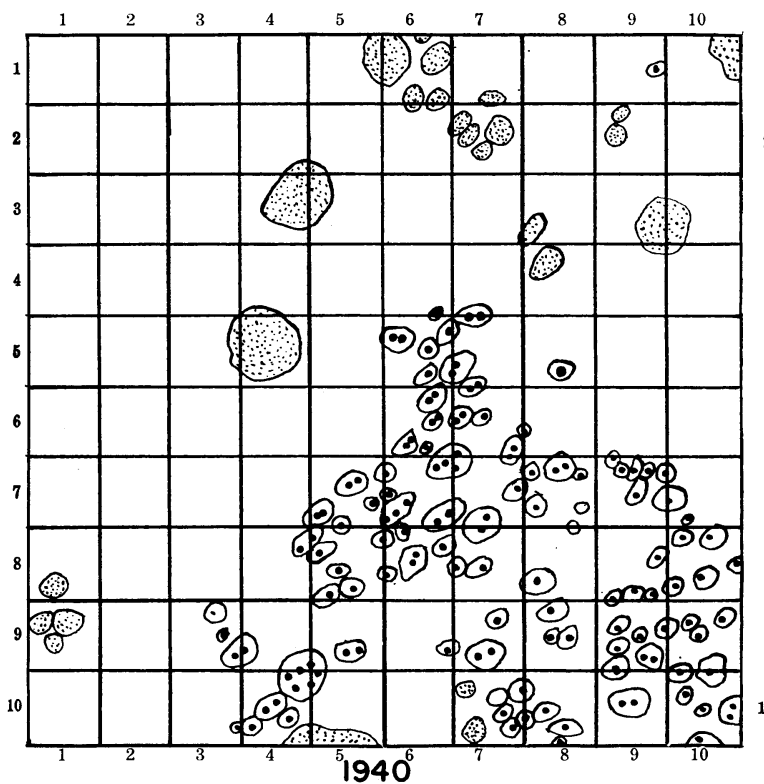

\section{\%:9:9 BUFFALO GRASS}

BLUE GRAMA GRA'SS

$8.3 \%$

4. $3 \%$
Native vegetation in class 4 pasture had been completely destroyed over large areas and it was with considerable difficulty that representative quadrats were located. The one shown in Figure 12D represents conditions better than the average. Basal area in 1940 was only 2 percent, being composed of 1.5 percent blue grama and .5 of buffalo grass. Of the total of 16.3 percent cover in 1941, blue grama constituted 5.2 and buffalo grass 11.1 percent. Thus,

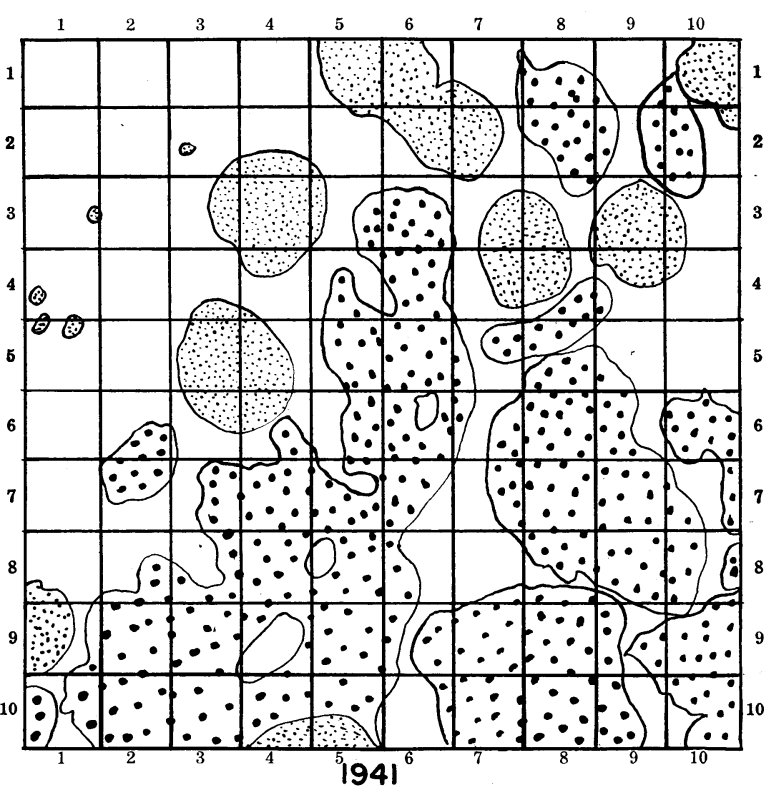

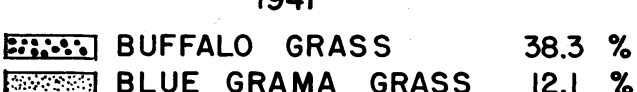

Fig. 12C. Square meter area in class 3 pasture near Ness City where heavy grazing had greatly reduced the cover in early years of the drought. 

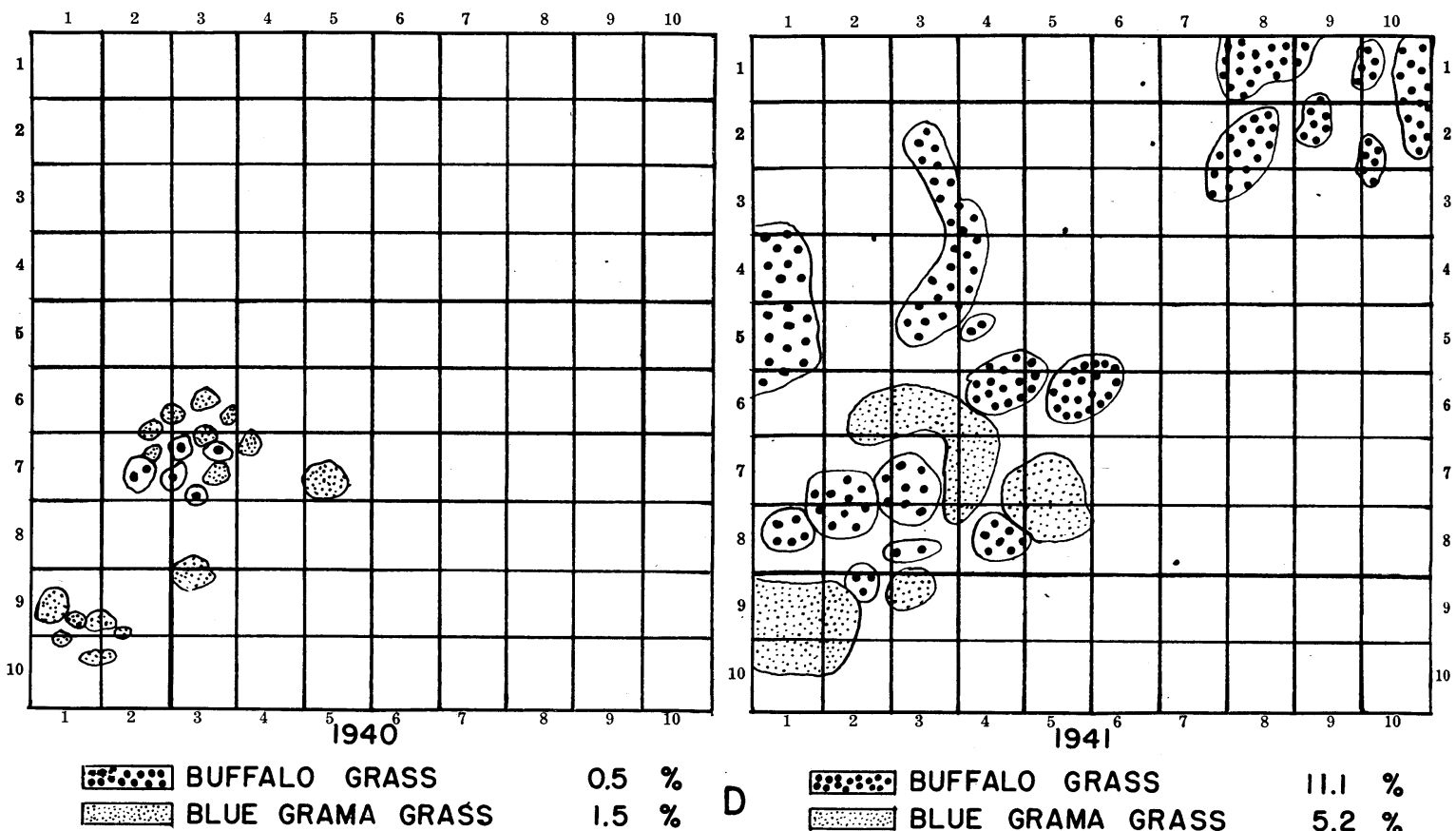

Fig. 12D. Typical quadrat in class 4 pasture at Ness City. There was no native vegetation in most of the area.

in all four pastures both species of short grass made good gains, but those of buffalo grass were the greater.

\section{Quinter Pastures}

Pastures in the vicinity of Quinter showed considerable variation in the intensity of grazing and amount of dusting. Those on rolling topography, which were usually largest, suffered least from adverse environmental conditions. Even under the most favorable circumstances, however, the extreme drought of 1939 destroyed much of the grass. In the spring of 1940, a large percentage of the short grass on the better pastures had lost the golden straw color which characterizes it when it is dormant but alive. Improvement during 1940 was extremely slow, due to the greatly weakened condition of the vegetation. It seemed as if the urge to grow had been almost completely lost by the drought-resistant relicts even though the plants were still alive.

Pastures on level or only slightly rolling topography were usually subjected to the most intense grazing and dusting, and consequently had suffered the greatest amount of damage. Frequently where the original vegetation had been largely or totally destroyed some of it was replaced by invading perennials such as Sporobolus cryptandrus, Schedonnardus paniculatus, or in extreme cases, by weedy annualsoften Salsola pestifer, Helianthus annuus, Chenopodium album, and Amaranthus retroflexus.

Class 1 pasture had an average cover of 5.7 percent in 1940. Buffalo grass was present throughout, but it was often concentrated in groups of small tufts. In Figure 13A, its average cover was only 1.6 percent. Blue grama furnished a cover of 2.3 and sand dropseed 1.8 percent. In the fall of 1941 buffalo grass had increased to 14.1 percent and blue grama to 4 . Sand dropseed had made a rather phenomenal growth, and even exceeded buffalo grass in increasing its area.

Although class 2 pasture had not been seriously overgrazed according to stocking records, continuous drought, especially in the fall of 1939, had nearly destroyed all vegetation. Relict plants were so weakened that the rainfall of 1940 , even though nearly normal, failed to produce any improvement. When charted in the fall, the total cover was only 3.3 percent (Fig. 13B). The gain during 1941 was somewhat below normal, due no doubt to the weakened condition of the grasses. The cover of buffalo grass was only 9.1 percent in 1941 and that of blue grama 13. Sand dropseed had only .4 percent basal cover.

Class 3 pasture, where dusting was much more severe than in either of the preceding, apparently did not suffer so greatly from the 1939 drought. Amount of vegetation in 1939 was considerably less than in the other pastures but the improvement during 1940 was much greater. Consequently in the fall of 1940, buffalo grass (7.9 percent) was much more abundant than in the better classes of pastures. During the next season it increased to 27.1 percent and blue grama to 7.4 (Fig. 13C).

Class 4 pasture had no native grass in its cover during either of the two years. Improvement in other pastures at this station occurred almost entirely in 1941, so severe had been the drought. But in 1941 good growth occurred, the gains made by buffalo grass equalling or exceeding those of blue grama. 

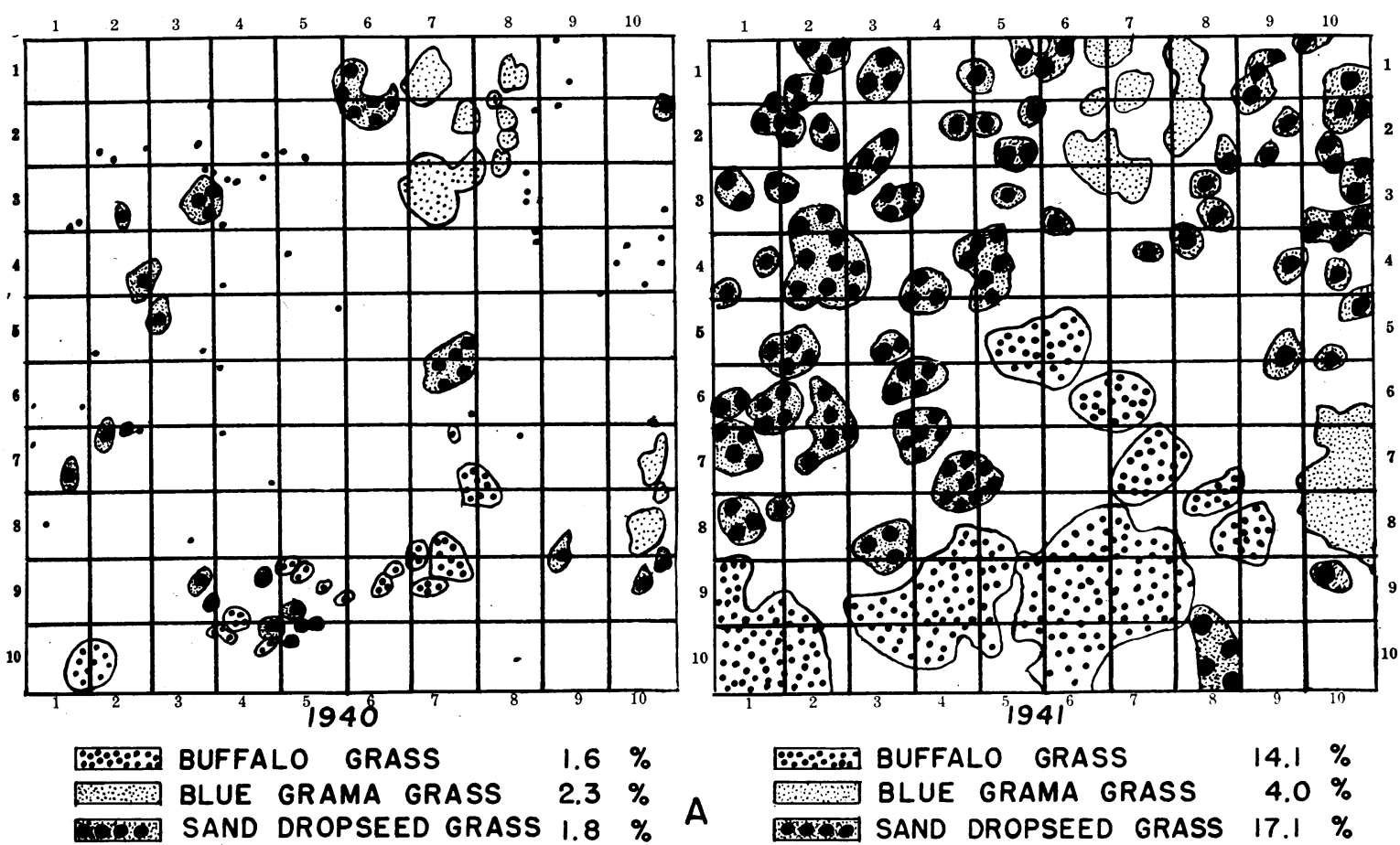

....... SAND DROPSEED SEEDLINGS

Fig. 13A. Quadrat typical of cover in class 1 pasture at Quinter. Sand dropseed invaded when the short grasses were killed.

\section{Dighton Pastures}

Range lands near Dighton had suffered somewhat less from dusting than those at Ness City, 30 miles eastward. Exceptions were pastures surrounded by cultivated fields. These had experienced extreme losses.

Class 1 pasture had not only been stocked lightly through most of drought years but it was surrounded
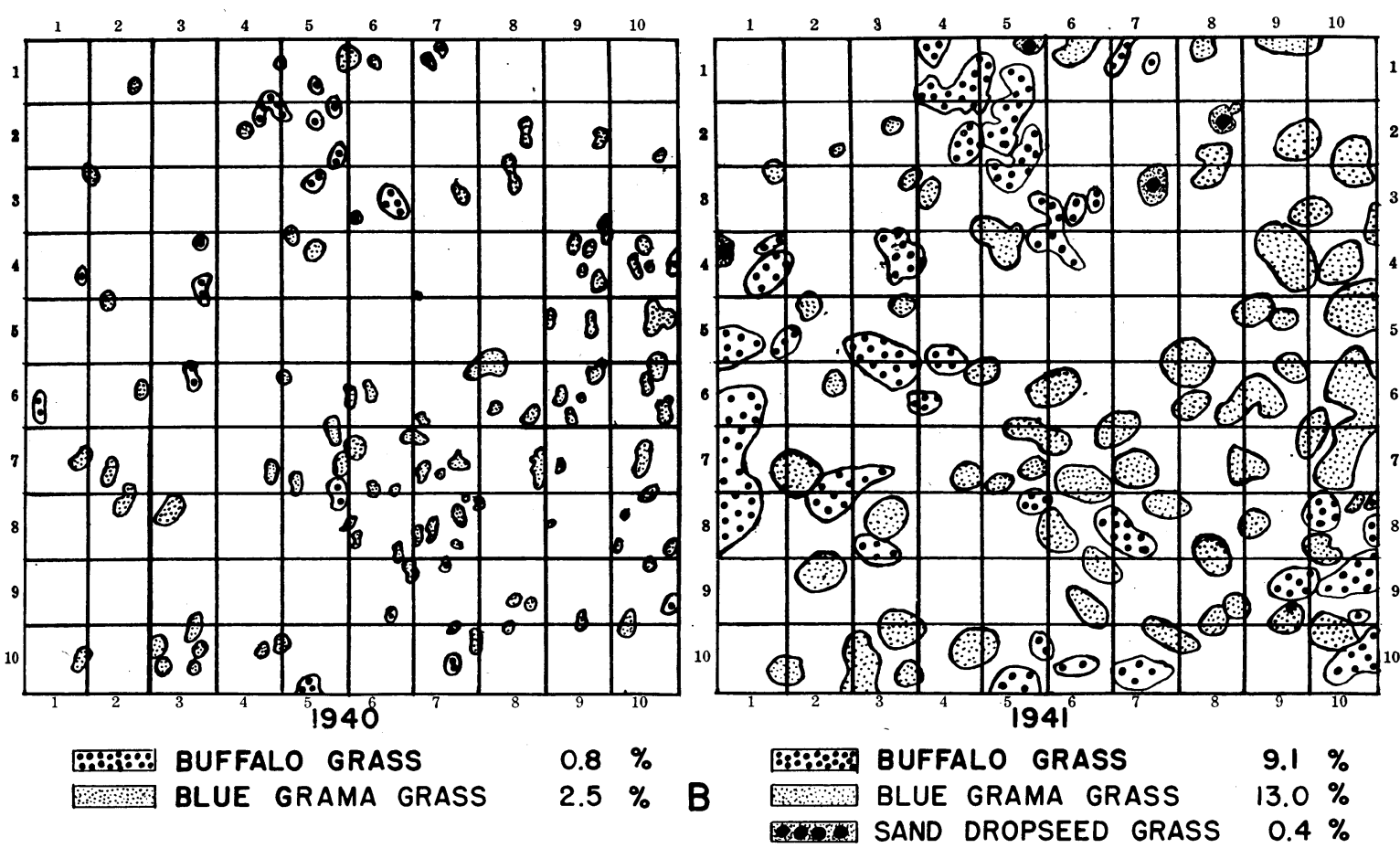

Fig. 13B. The small tufts of short grass in this class 2 pasture quadrat at Quinter are typical of ranges where drought had been severe. Where the damage was caused by dust the tufts were usually farther apart. 


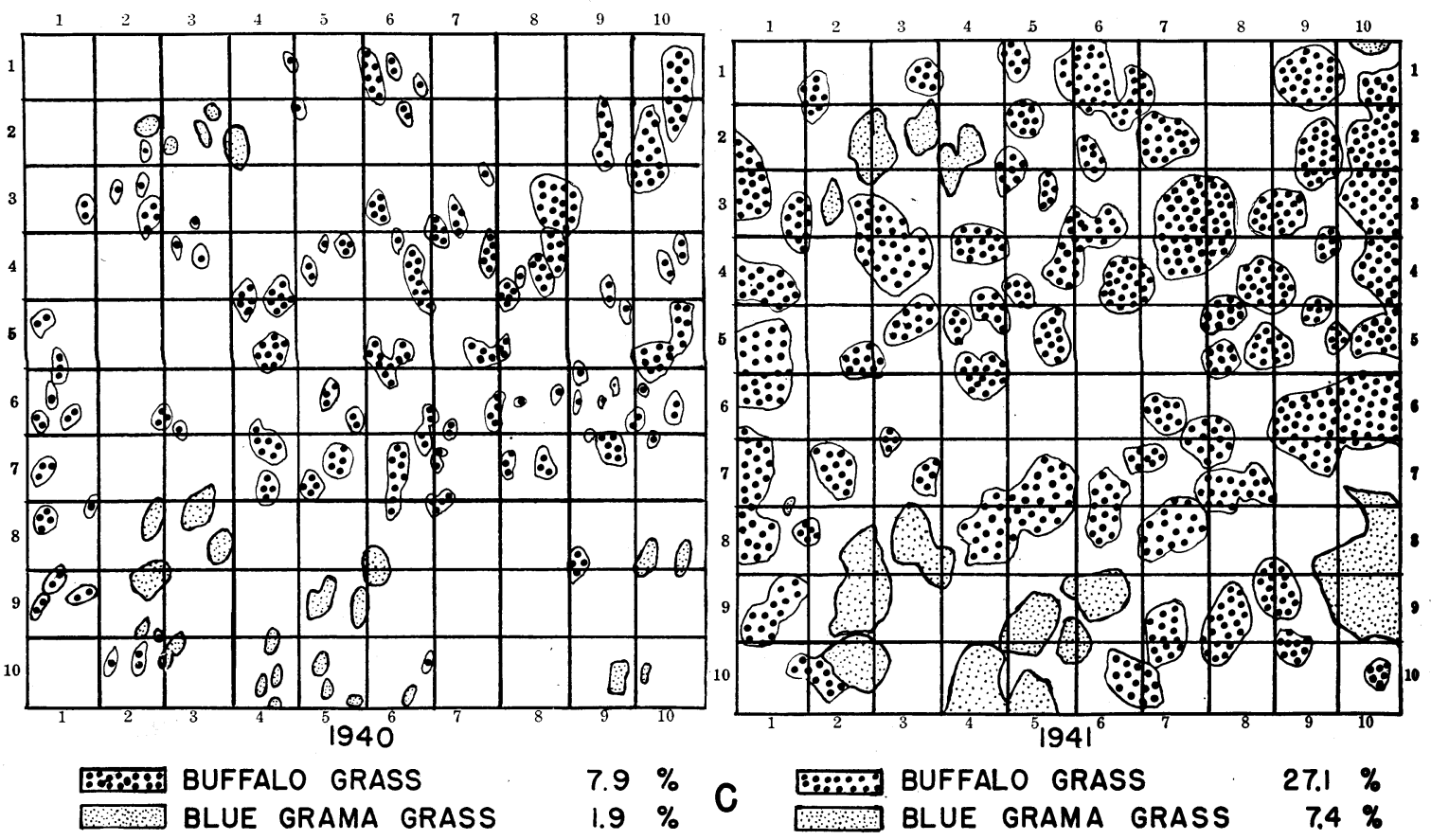

Fig. 13C. Class 3 pasture at Quinter which was dusted badly in 1935. The cover was uneven because of the destruction of vegetation by dust.

by other pastures. Therefore the intensity of dusting was reduced to a minimum in comparison with that of the other prairie land in the community. The cover of the pasture was from 15 to 20 percent in 1939 (Fig. 14A). The loss during the late fall, however, was severe and growth during 1940 was meager in comparison with that of nearby pastures. This was due primarily to variations in local showers. The cover in the fall of 1940 was only 10.6 percent, 6 percent of which was blue grama and 4.6 percent buffalo grass. The excellent environmental conditions during the summer of 1941 resulted in vigorous growth. The small tufts of blue grama were greatly enlarged and the cover in 1941 was increased to 11 percent. Buffalo grass increased in the usual manner, sending out myriads of long stolons. Its basal area increased to 43.5 percent.

Changes of cover in this pasture were given further study. The remarkable inerease in basal area from less than 1 percent in August, 1940 (which was only about one tenth of that in late fall recorded above), to 80 percent in July, 1942, has been recorded by photographs. The severe drought in the fall of 1939 reduced the cover of about 18 percent to only 1 percent by August of the next year (Figs. $14 \mathrm{~A}$ and B). This left nearly all of the soil exposed to erosion. The rains during the spring of 1940 were sufficient to cause the soil to form a crust and thus become especially susceptible to loss of moisture through evaporation. The dark areas in Figure 14B are due to flaking of the surface soil and its removal by wind. This process has furnished abundant materials for many dust storms. The increase in cover during 1940 occurred because of ample rains in August and September. The basal area of vegetation increased to about 11 percent. (Fig. 14C) The increase was due not only to the enlargement of each tuft of grass but also to an actual increase in the number of tufts through revival of the half dead crowns just beneath the surface of the soil. Growth began early in 1941. By the last of May the ground cover had increased to about 20 percent. Rapid growth occurred during spring and early summer and in early July the cover averaged 30 percent. Another 10 percent was added before the short period of drought occurred in August. Further plant growth in the autumn occupied another 15 percent of the bare soil. Tufts of buffalo grass had rapidly developing stolons projecting outward in every direction. These leafy offshoots formed approximately four fifths of the total basal area. Still further improvement in the vegetation in July, 1942, is shown in Figure $14 \mathrm{D}$ when perennial pasture grasses, mostly buffalo grass, covered 80 percent of the soil.

Although the original basal area was nearly restored by midsummer of 1942 , its composition was very different from that at the beginning of the drought. In 1933, buffalo grass and blue grama were about equally represented. In 1942 the former comprised at least 75 percent of the mixture of the two dominants. Perennial forbs had been almost exterminated.

In class 2 pasture, ground cover was 19.2 percent in the fall of 1940 . Blue grama constituted 3.8 percent and buffalo grass 15.4. The greater amount of buffalo grass was doubtless due to the increase of this species during the summer. Blue grama was 


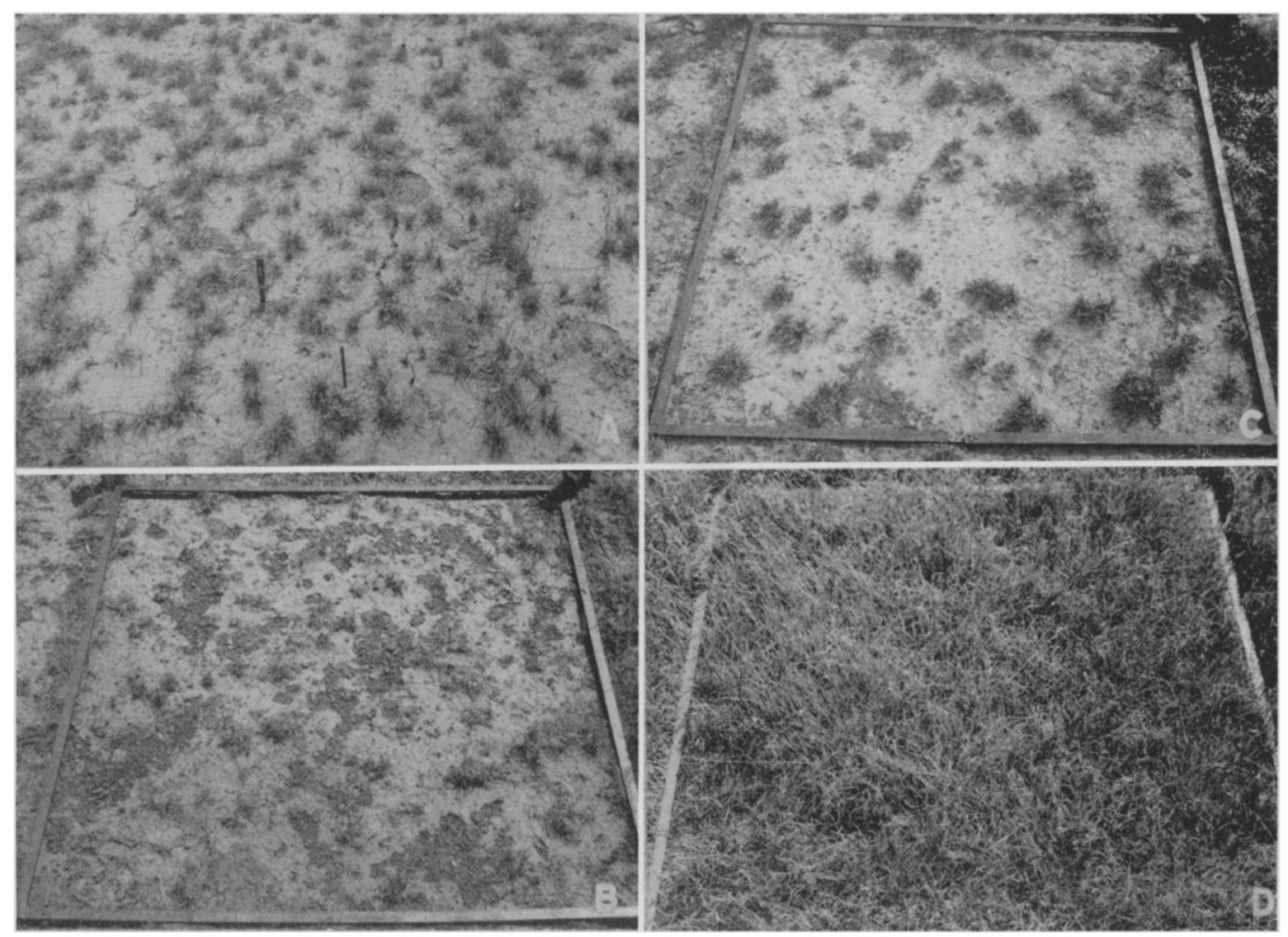

Fig. 14. A. View of short grass in elass 1 pasture at Dighton in September, 1939, when the basal cover was 15 to 20 percent. B. Quadrat in class 1 pasture at Dighton on August 1, 1940, before any recovery had occurred fron the dronght of 1939. Basal cover is 1 percent. Note the loss of surface soil. C. Same quadrat as in $B$. The cover is now 10.6 percent, an increase of tenfold in 60 days. Photo September 28, 1940. D. Same quadrat as it appeared on July 7, 1942. Buffalo grass has increased greatly and the basal cover is 80 percent.

reduced to 3.1 percent in 1941 , but buffalo grass increased nearly fivefold and composed 74.7 percent of the grass when charted in late fall.

In class 3 pasture, the cover was 21 percent in 1940. Here again, buffalo grass furnished the larger amount. It grew rapidly during the season of 1941 and increased its initial cover of 15.1 percent to 46.6 . The number of tufts of blue grama was reduced considerably, but due to the enlargement of those that did survive the former cover of 5.9 percent was decreased only about one third.

Class 4 pasture had been closely grazed for many years. Dusting, particularly in 1935, was very severe. The drifts of soil were so high and numerous that it was impossible to drive over this area for several years following the worst storms. The native plants were completely smothered over most of the pasture. The cover, largely blue grama, was never greater than 3.4 percent (Table 1).

This group of pastures represents well the drastic changes that the vegetation had undergone, the actual loss or at least slow recuperation of blue grama which was all but destroyed, and the extremely rapid recovery and wide spread of buffalo grass as soon as conditions favorable to its growth occurred.

\section{Discussion}

The pastures were examined in the fall of 1939 when the drought was so intense that it was impossible to separate with certainty living, dormant plants from those that were dead. Although the plots were selected and fenced in early spring of 1940, amount of living vegetation could not be determined until the occurrence of rains and revival of the vegetation. It was for this reason that quadratting was not done until fall. Hence, the basal area was measured only after a summer of very variable growth under subnormal and unevenly distributed rainfall. Consequently, although the cover was invariably least in class 4 pastures it was not always greatest in class 1 . The exceptions were at Quinter where the class 3 pasture recovered best, and at Dighton where both class 2 and 3 pastures had nearly twice as much cover as class 1 . If the 16 pastures at all four stations are considered together as a sampling of a very large range area, then the average cover in 1940 in classes 1 to 4 was 18.0, 13.7, 13.4 and 2.2 percent, respectively.

When in 1941 an excellent season for growth occurred after nine or more dry years, these pastures 
extended their cover to $56.8,46.3,44.3$, and 17.2 percent, respectively. The grasses in class 1,2 , and 3 pastures tripled their basal cover, those in class 4 increased nearly eightfold. Increases in most of the individual pastures were twofold (only one less) to fourfold. Class 1 pastures at Quinter and Dighton increased their previous cover approximately 6 and 5 times, respectively, and class 4 at Ness City 8 times. Class 2 at Quinter, where growth the previous year in all pastures was poor, increased its cover sevenfold, and the cover in class 4 pasture at Hays became ten times as great in a single summer.

These results illustrate the wonderful recuperative powers of both blue grama, the most drought resistant species of the midwest (Mueller \& Weaver. 1942), and buffalo grass, which spreads vegetatively with great rapidity. Except for sand dropseed, which occurred in certain pastures and has during the past few years spread widely over the plains, it seems certain that seedling grasses played a very minor role in the process of recovery. This is in agreement with the earlier extensive work of Savage (1937) and Weaver and Albertson (1936). Albertson and Weaver (1942) in their seven-year study of ranges in Kansas, state: "Despite quantities of seedlings, and rapid propagation of buffalo grass by stolons in 1935 and at other times, periods favorable to growth were usually too short to result in establishment. Flower stalks were sometimes formed but few seeds matured. With dusting and denudation rainfall became less efficient and runoff greatly increased." Weaver and Mueller (1942) ascertained that the average distribution of perennial grass seedlings in mixed prairie in June, 1941, was only 2.4 per square foot. They state that the probability of the seedlings of the dominant range grasses completing their life cycle by production of seeds the first year is remote, since a continuous moisture supply rarely occurs. Even if all the seedlings of perennial grasses (exclusive of the stoloniferous buffalo grass) had survived and made a maximum growth they would have increased the cover less than two percent.

Since most of the increase in cover was due to buffalo grass, its abundance in the several pastures as compared with blue grama is important. In the fall of the first year, blue grama exceeded buffalo grass in abundance in all class 1 and 2 pastures, except class 1 at Hays and class 2 at Dighton. Average amount of each short grass in the group of four class 1 and four class 2 pastures was about the same. At the end of 1941 there was about 4.5 times as much buffalo grass as blue grama in the average of class 1 pastures and about 3 times as much in the average of class 2 pastures. Moreover, the buffalo grass exceeded blue grama in amount in 7 of the 8 pastures of the first and second classes. In the average of class 3 and 4 pastures in 1940, buffalo grass ranked greater in basal cover than blue grama in the ratio of about 3 to 2 and 5 to 4 , respectively. Blue grama ranked first in only 2 individual ranges. Buffalo grass was not represented in one class 3 pasture either in 1940 or 1941. Otherwise it was most abundant in all in 1941, and its average basal cover was nearly 5 times that of blue grama in the other three pastures. The grasses in only a single pasture in class 4 may be compared in 1940 since either one or the other of the short grasses was absent in three. But buffalo grass was twice as abundant as blue grama in the fourth. Thus, buffalo grass ranked higher when it was present in 1941, in every range except one. Its average basal cover (34.3 percent) was 3.2 times greater than that of blue grama.

\section{ANNUAL YIELD OF NATIVE GRASSES AND WEEDS}

Total yields of short grass, mid grass, and weeds were obtained in each class of pasture at the several stations including Phillipsburg. All yields are expressed in pounds per acre. ${ }^{4}$

\section{Hays Pastures}

Class 1 range had a fairly even cover of 37.1 percent in the fall of 1940 which yielded 1,378 pounds per acre (Table 2). By 1941 the cover had increased to 96 percent. but the average yield increased much less. It was 1,524 pounds (Fig. 15). It is significant that the yield of weeds (mostly Hordeum pusillum and Festuca octoflora) was only 391 pounds in 1940 but 707 in 1941 . The open places in the sod were usually more densely populated by ruderals than were the smaller and less numerous ones where the cover had suffered little or no deterioration. In most locations where the cover of short grass remained nearly normal, the seeds of many weedy plants failed to make sufficient contact with the soil to insure germination. The few scattered seedlings

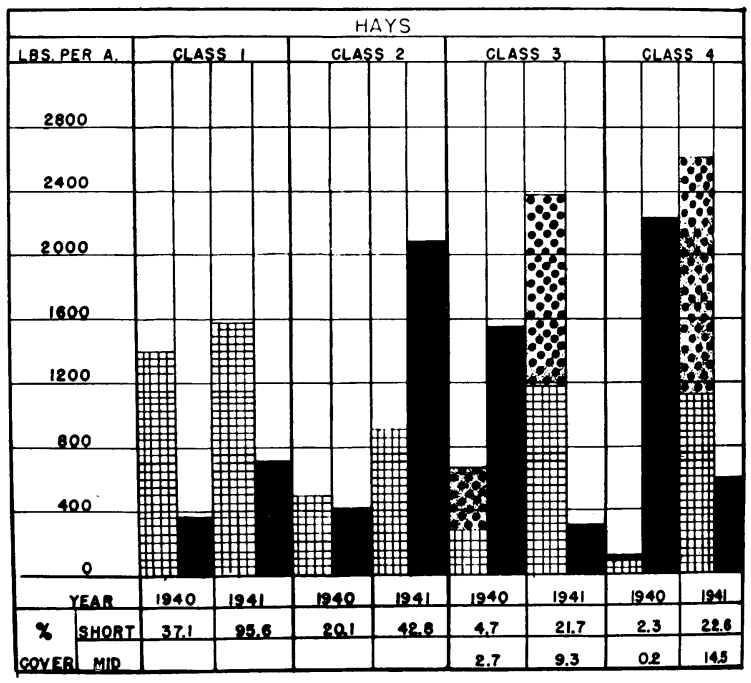

FIG. 15. Percentage basal cover and yield in pounds per acre of short grass (crosshatch), mid grass (dots), and weeds (black) in the several pastures at Hays in 1940 and 1941.

4 Annual yields are based on a slightly different percent of cover than that given in Table 1 , since more quadrats were included. 
growing in these places barely survived the competition for water and light and their presence had little effect upon the growth of the native vegetation.

TABLE 2. Basal cover and plant yield in the several pastures.

\begin{tabular}{|c|c|c|c|c|c|c|c|}
\hline \multirow{2}{*}{ Class } & \multirow{2}{*}{ Year } & \multicolumn{2}{|c|}{$\begin{array}{l}\text { Percent } \\
\text { Cover }\end{array}$} & \multicolumn{4}{|c|}{ Yield In Pounds Per Acre } \\
\hline & & $\begin{array}{c}\text { Short } \\
\text { grass }\end{array}$ & $\underset{\text { grass }}{\text { Mid }}$ & $\begin{array}{l}\text { Short } \\
\text { grass }\end{array}$ & $\underset{\text { grass }}{\text { Mid }}$ & $\begin{array}{l}\text { Total } \\
\text { grass }\end{array}$ & Weeds \\
\hline \multicolumn{8}{|c|}{ HAYS } \\
\hline \multirow[t]{2}{*}{$1 \ldots \ldots \ldots$} & 1940 & 37.1 & $\ldots$ & 1,378 & $\ldots \ldots$ & 1,378 & 391 \\
\hline & 1941 & 95.6 & $\ldots$ & 1,524 & & 1,524 & 707 \\
\hline \multirow[t]{2}{*}{$2 \ldots \ldots \ldots$} & 1940 & 20.1 & $\cdots$ & 534 & & 534 & 432 \\
\hline & 1941 & 42.8 & & 902 & & 902 & 2,085 \\
\hline \multirow{2}{*}{$3 \ldots \ldots \ldots$} & 1940 & 4.7 & 2.7 & 231 & 378 & 609 & 1,546 \\
\hline & 1941 & 21.7 & 9.3 & 1,170 & 1,226 & 2,396 & 292 \\
\hline \multirow{2}{*}{$4 \ldots \ldots \ldots$} & 1910 & 2.3 & 0.2 & 110 & 23 & 133 & 2,277 \\
\hline & 1941 & 22.6 & 14.5 & 1,092 & 1,455 & 2,547 & 596 \\
\hline \multicolumn{8}{|c|}{ NESS CITY } \\
\hline \multirow{2}{*}{$1 \ldots \ldots \ldots \ldots$} & 1940 & 21.0 & $\cdots$ & 703 & $\cdots \cdots$ & 708 & 1,270 \\
\hline & 1941 & 45.0 & 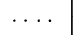 & 1,390 & $\ldots \ldots$ & 1,590 & 1,729 \\
\hline \multirow[t]{2}{*}{$2 \ldots \ldots \ldots$} & 1940 & 11.0 & & 478 & $\ldots \ldots$ & 478 & 1,655 \\
\hline & 1941 & 42.6 & . & 1,610 & & 1,610 & 1,240 \\
\hline \multirow[t]{2}{*}{$3 \ldots \ldots \ldots$} & 1940 & 10.2 & & 459 & & 459 & 1,045 \\
\hline & 1941 & 49.6 & & 2,810 & & 2,810 & 650 \\
\hline \multirow{2}{*}{$4 \ldots \ldots \ldots$} & 1940 & 4.3 & & 118 & & 118 & 892 \\
\hline & 1941 & 22.0 & & 752 & $\ldots \ldots$ & 752 & 1,215 \\
\hline \multicolumn{8}{|c|}{ QUINTER } \\
\hline \multirow{2}{*}{$1 \ldots \ldots \ldots$} & 1940 & 4.0 & 3.0 & 99 & 52 & 151 & 1,890 \\
\hline & 1941 & 23.7 & 10.0 & 1,081 & 1,517 & 2,598 & 2,099 \\
\hline \multirow[t]{2}{*}{$2 \ldots \ldots \ldots \ldots$} & 1940 & 1.7 & $\ldots$ & 41 & $\ldots \ldots$ & 41 & 1,262 \\
\hline & 1941 & 18.5 & $\ldots$ & 686 & $\ldots \ldots$ & 686 & 1,850 \\
\hline \multirow[t]{2}{*}{ 3. $\ldots \ldots \ldots$} & 1940 & 6.9 & 0.2 & 104 & $\ldots \ldots$ & 104 & 2,094 \\
\hline & 1941 & 32.0 & 1.2 & 1,511 & 226 & 1,737 & 2,184 \\
\hline \multirow[t]{2}{*}{$4 \ldots \ldots \ldots \ldots$} & 1940 & $\ldots$ & $\ldots$ & $\ldots \ldots$ & $\ldots \ldots$ & $\ldots \ldots$ & 2,700 \\
\hline & 1941 & & & & & $\ldots \ldots$ & 2,010 \\
\hline \multicolumn{8}{|c|}{ DIGHTON } \\
\hline \multirow{4}{*}{$\begin{array}{l}1 \ldots \ldots \ldots \ldots \\
2 \ldots \ldots \ldots \ldots\end{array}$} & 1940 & 10.9 & $\ldots \ldots$ & 108 & . & 106 & 1,413 \\
\hline & 1941 & 55.3 & $\ldots$ & 1,854 & $\ldots \ldots$ & 1,854 & 108 \\
\hline & 1940 & 20.0 & $\ldots$ & 187 & $\ldots \ldots$ & 187 & 1,233 \\
\hline & 1941 & 72.9 & $\ldots \ldots$ & 2,412 & $\ldots \ldots$ & 2,412 & 52 \\
\hline \multirow[t]{2}{*}{$3 \ldots \ldots \ldots \ldots$} & 1940 & 17.0 & $\ldots$ & 184 & $\ldots \ldots$ & 184 & 185 \\
\hline & 1941 & 67.5 & $\ldots$ & 2,401 & & 2,401 & 40 \\
\hline \multirow[t]{2}{*}{$4 \ldots \ldots \ldots \ldots$} & 1940 & 2.2 & $\ldots$ & 98 & & 98 & 1,210 \\
\hline & 1941 & 3.4 & 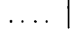 & 360 & $\cdots$ & 360 & 1,985 \\
\hline \multirow{3}{*}{$1 \ldots \ldots \ldots$} & \multicolumn{5}{|c|}{ PHILLIPSBURG } & & \\
\hline & 1940 & 4.8 & 0.3 & 163 & 14 & 177 & 864 \\
\hline & 1941 & 16.1 & 1.2 & 709 & 92 & 201 & 3,376 \\
\hline
\end{tabular}

Class 2 pasture with an average cover of 20.1 percent yielded 534 pounds in 1940 and 902 in 1941 . Here the yield increased more in proportion to increase in cover. The vegetation on this range was somewhat patchy, caused by differences in density and height of the dominants (Fig. 16). Yield of weeds in 1940 was only 432 pounds but, due to a dense stand of Hordeum pusillum, in 1941 it increased to 2,085 pounds.

Hordeum pusillum was often represented by 6,000 to 8,000 plants per square meter (Fig. 17). They formed a dense stand, frequently 20 inches high and resembled a field of cultivated barley. The shoots of the short grasses were dwarfed and scarcely able to carry on photosynthesis with the small amount of sunlight that diffused through the overtopping little

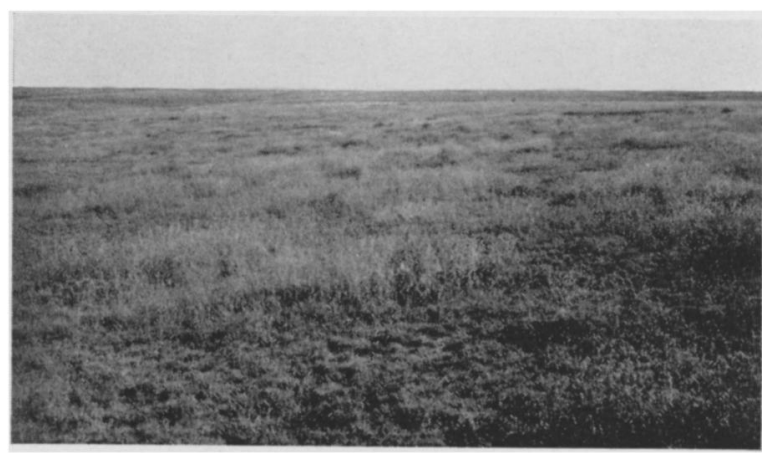

FIG. 16. View of class 2 pasture at Hays. Differences in height are due to alternating patches of blue grama and buffalo grass and to intensity of grazing. September, 1939.

barley. Yield of perennial grasses was materially reduced where the stand of this weed was so dense that growth in the spring was seriously delayed. The harmful effect of little barley upon the growth of the short grasses was further complicated by the fact that after ripening, early in June, it lodged and formed a dense mat which completely overtopped the short grasses.

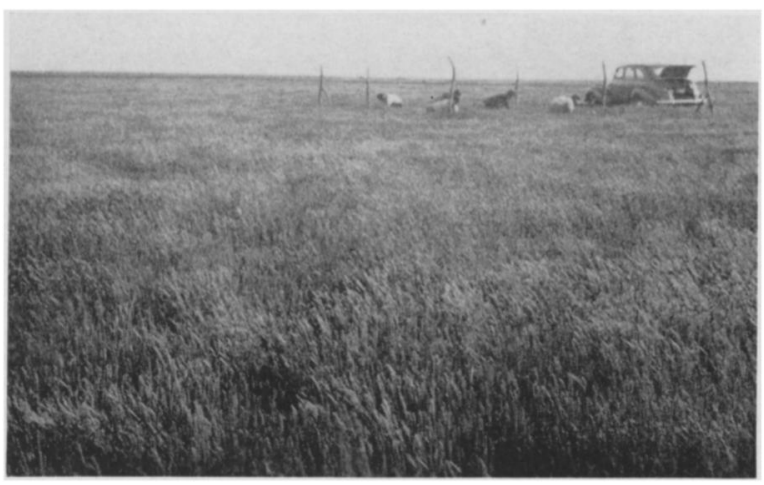

Fig. 17. View of class 1 pasture where the short grasses are overtopped by a dense stand of Hordeum pusillum. More than a ton per acre of this weedy grass was often produced in pastures of west-central Kansas.

In class 3 pasture, the basal cover was considerably less than in classes 1 and 2 . It had the characteristic open-bunch appearance that so often occurred when dusting had been severe. The isolated bunches of blue grama that survived the adverse environmental conditions during the previous years of drought spread rapidly, due to the growth of new tillers. Sand dropseed behaved in a manner very similar to that of blue grama. The growth of both grasses was unusually rank in 1941 which accounts for the heavy production. Yield of short grass in 1940 was only 231 pounds, but that of mid grass was 378. In 1941, yield of short grass was 1,170 pounds and that of mid grass, 1,226. Thus, the increases were about fivefold and fourfold, respectively. Yield of weeds, mostly Lepidium densiflorum, averaged 1,546 pounds in 1940 and greatly reduced the amount 
of water available to the grasses. The unusually cool, wet spring of 1941 was not conducive to growth of weeds and their yield was reduced to only 292 pounds.

Class 4 pasture had almost no cover in the spring of 1940. Yields of short grass and mid grass during this year were only 110 and 23 pounds, respectively. In 1941 the cover of both was greatly increased. The harvest of short grass yielded 1,092 pounds and that of mid grass 1,455. Thus, the mid grass with only slightly more than half as great a basal area as short grass yielded more (Fig. 15). Sand dropseed is not only a very drought resistant species but it also furnishes a moderately good grade of forage.

\section{Ness City Pastures}

Class 1 pasture had a basal cover of 21 percent in 1940, which was the result of good management during the previous years of severe drought. The yield of short grass was 708 pounds. By 1941 the cover had increased to 45 percent and the yield to 1,390 pounds (Fig. 18). There were no mid grasses in any of the Ness City pastures. Hordeum pusillum formed a dense stand throughout most of class 1 pasture and yielded 1,270 pounds in 1940 and 1,729 in 1941 . Thus, the yield of this weedy annual even in the best pasture type exceeded one half ton and was far greater than that of native perennials during both years.

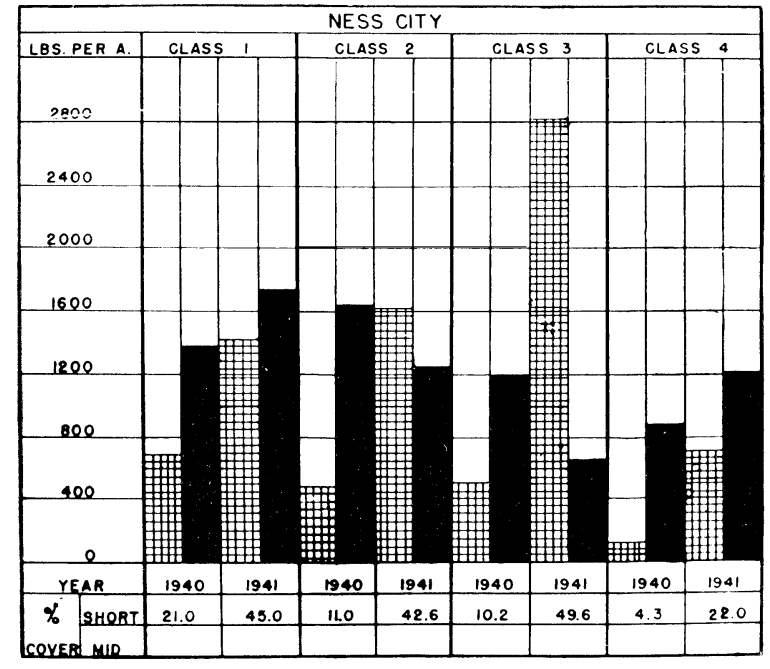

Fig. 18. Percentage basal cover and yield in pounds per acre of short grass (crosshatch) and weeds (black) at Ness City.

Class 2 pasture, located less than a mile from the first, had been subjected not only to more severe grazing but also to a greater degree of dusting. The short-grass cover of 11 percent in 1940 yielded only 478 pounds. The improvement was rapid, however, during the growing season of 1941 and the vield of short grass was 1,610 pounds from a cover of 42.6 percent. Thus, cover and yield increased in almost the same proportion. The yield of weeds, mostly
Chenopodium album, was 1,655 pounds in 1940 but much less, 1,240 pounds, in 1941 .

Cover in class 3 pasture was reduced to only $\mathbf{1 0 . 2}$ percent in 1940 ; the yield of short grass was 459 pounds. But in 1941 great improvement occurred, and the short-grass cover of 49.6 percent produced the very high yield of 2,810 pounds. Yield of weeds was 1,045 pounds in 1940 but only 650 in 1941 .

Class 4 pasture had a sparse initial cover of 4.3 percent. Growth was slow and an average acre yield of only 118 pounds was harvested during 1940. The cover had increased to 22 percent in 1941 from which 752 pounds of short grass were harvested. The weed population was composed of Chenopodium album, Helianthus annuus, Salsola pestifer, Eragrostis cilianensis, and Euphorbia marginata (Fig. 19). A total of 892 and 1,215 pounds was harvested during the seasons of 1940 and 1941, respectively.

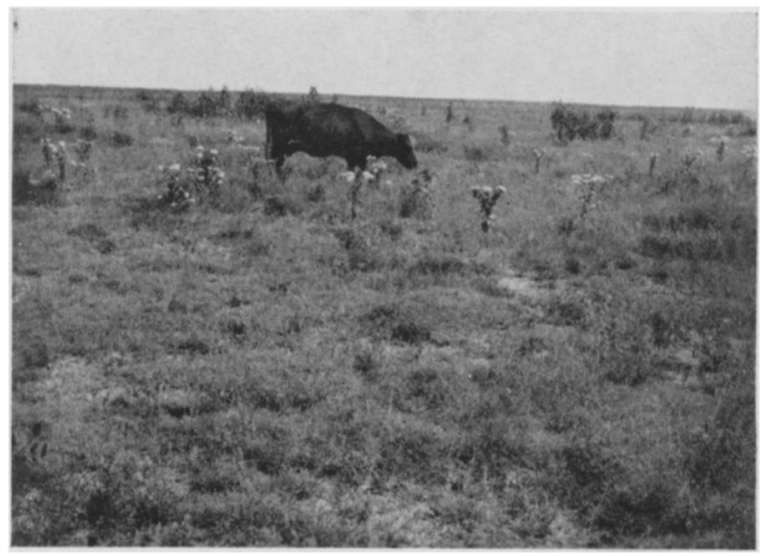

Fia. 19. Class 4 pasture at Ness City in August, 1941. Much of the soil had been partially reclothed with buffalo grass.

The variability of the weed population in these disclimax short-grass prairies, where half or less than half of the surface was occupied, is shown by the great variation in the production of ruderals. Under conditions 1 and 4 (Table 2) the population of weeds increased in 1942 over that of the previous year, while under conditions 2 and 3 it dimin:shed.

\section{Quinter Pastures}

Class 1 pasture had been subjected to severe dusting in 1935, but to little thereafter. Grazing was moderate. The 4 percent basal cover of short grass yielded only 99 pounds in 1940 and a 3 percent cover of mid grass (Sporobolus cryptandrus) 52 pounds (Fig. 20). Both species made considerable gains in 1941 when the cover was 23.7 and 10 percent, respectively. The yield of short grass was 1,081 pounds and that of the mid grass, 1,517. Lepidium densiflorum, Monolepis nuttalliana, and other weeds yielded 1,890 pounds in 1940 and 2,099 in 1941 .

A cover of 1.7 percent in class 2 pasture yielded only 41 pounds in 1940. The basal area increased to 18.5 percent in 1941 and the yield to 686 pounds. Thus, the basal area was 11 times greater and the 


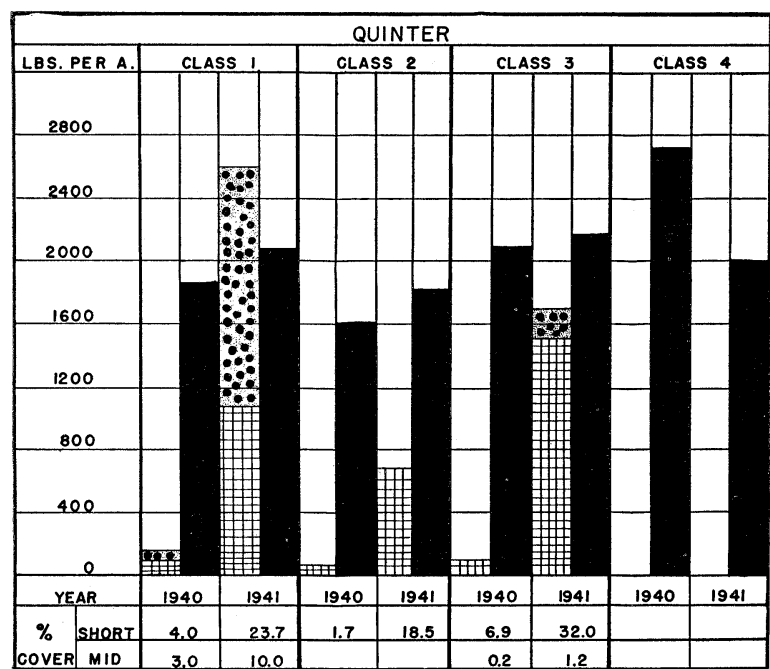

Fig. 20. Basal cover and yield in pounds per acre of short grass (crosshatch), mid grass (dots), and weeds (black) at Quinter.

yield about 17 times more than in the preceding year. There was a heavy yield of weeds each year, 1,262 and 1,850 pounds, respectively.

Class 3 pasture had been grazed similarly to that of class 2 but the degree of dusting was much greater, in fact, large drifts of soil were common. The damage from the drought of 1939 appeared to be less on this area than on class 2 pasture. The cover of short grass in 1940 was 6.9 percent, and it yielded 104 pounds. Basal cover increased to 32 percent in 1941 and the acre yield to 1,511 pounds. The cover of Sporobolus cryptandrus was negligible in 1940 but by 1941 it was 1.2 percent and yielded 226 pounds. Weeds in 1940 were composed primarily of Salsola pestifer, Amaranthus retroflexus, and Chenopodium album (Fig. 21). Yields in 1940 and 1941 were 2,094 and 2,184 pounds per acre, respectively. Thus, the foliage cover in all the Quinter pastures was high and to the casual observer their condition appeared to be good.

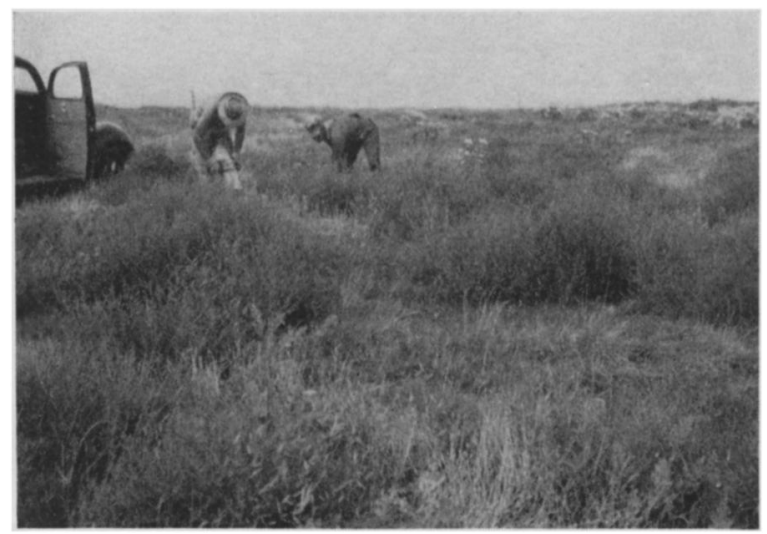

FiG. 21. View of class 3 pasture at Quinter. Large plants of Salsola pestifer and other weeds form a fairly continuous cover over the short grass beneath.
The class 4 pasture had been subjected to heavy grazing for several years previous to 1940, and dusting from adjacent cultivated fields was extreme in 1935 and occasionally severe subsequently. As a consequence, the native vegetation had been practically destroyed. No native grasses were found in the areas marked for clipping. Weeds, however, were abundant. Large plants of Salsola pestifer 2 to 3 feet high, and 4 to 6 feet in diameter were common. The yield of weeds in 1940 was 2,700 pounds and in 1941 it was 2,010 pounds.

\section{Dighton Pastures}

Class 1 pasture was composed of short grasses and weeds; here, as at Ness City, no mid grasses occurred in the clip quadrats (Fig. 22). The cover in 1940 was 10.9 percent and the yield was 106 pounds. In 1941, the cover had increased to 55.3 percent and the yield to 1,854 pounds. The yield of weeds, primarily Lepidium densiflorum, was 1,413 pounds in 1940, but only 108 in 1941 .

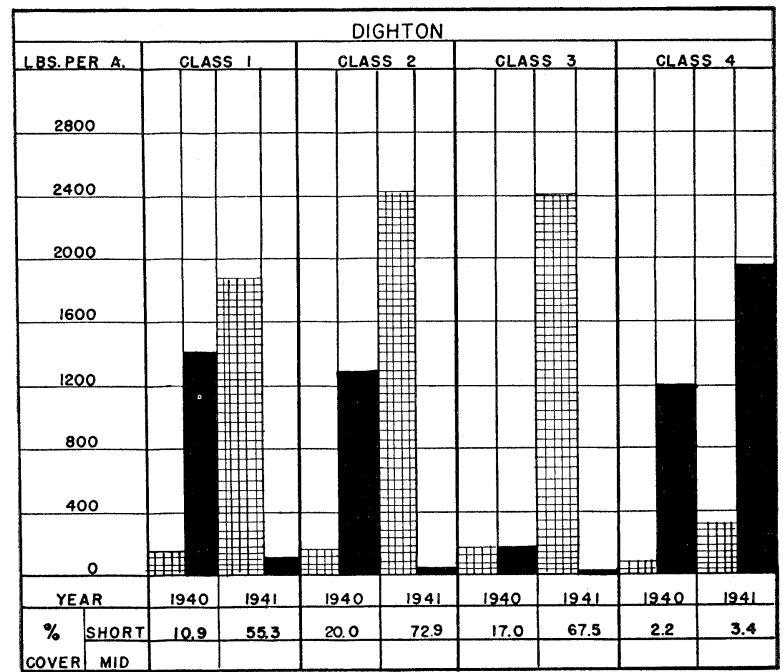

Fig. 22. Percentage basal cover and yield in pounds per acre of short grass (erosshatch) and weeds (black) at Dighton.

Class 2 pasture, with 20 percent cover, yielded 187 pounds of short grass in 1940 . The next year the cover had increased to 72.9 percent and it yielded 2,412 pounds. The yield of weeds was 1,233 pounds the first year, but only 52 the second. Thus, while weeds were abundant at the preceding station, conditions for germination and establishment were poor here despite the presence of abundant seed.

Class 3 pasture had a cover of 17 percent in 1940 and yielded 184 pounds of short grass. The cover during the next year increased to 67.5 percent and yielded 2,401 pounds. The yield of weeds was almost negligible being 185 pounds in 1940 and 40 in 1941.

Class 4 pasture was grazed severely previous to 1935. The dusting from adacent cultivated fields was extremely severe during the spring and as a con- 
sequence most of the vegetation was smothered. The cover of short grass in 1940 averaged only 2.2 percent, from which only 98 pounds were harvested. In 1941 it increased to 3.4 percent and the yield of short grass to 360 pounds. Weeds were abundant. Yields of 1,210 and 1,985 pounds, respectively, were obtained in 1940 and 1941.

Class 1 pasture at Phillipsburg (actually a droughtand dust-depleted mid-grass prairie) yielded 163 pounds per acre of short grass in 1940 from a cover of 4.8 percent. ${ }^{5}$ The yield of mid grass, nearly all Bouteloua curtipendula, was only 14 pounds from .3 percent cover. In 1941 the cover of short grass had increased to 16.1 percent from which 709 pounds per acre were harvested. The yield of mid grass was 92 pounds from 1.2 percent eover. The yield of weeds, mostly Lepidium densiflorum and Hordeum pusillum, was 864 pounds per acre in 1940 but during the next year of more abundant rainfall 3,376 pounds.

\section{Discussion}

Examination of the data shows that there is only a general correlation between cover and yield. This is because of the great variability in vigor of the drought-stricken vegetation at the several stations and differences in degree of burial by dust in different pastures. This resulted in varying degrees of dormancy and protection from drought. Moreover, differences in time and amount of water available for growth prevented close agreement between amount of basal cover and yield. Some relationships, however, stand out plainly. During the good year of growth (1941) the weakened vegetation was greatly invigorated. But at both Hays and Ness City the production per unit of plant cover in class 1 and 2 pastures decreased compared with the yield in 1940 when the basal cover was much smaller (Table 3 ). In class 3 and 4 pastures where dusting had been heavy and the original cover very open, production per unit basal cover increased. At Ness City this increase was great.

At Quinter and Dighton there were increases in yield per unit percent of cover in all classes of pastures. Gains in classes 1 to 3 varied only from 21 to 32 pounds per unit of cover, except in class 2 at Quinter where the gain was only 13 pounds. The gain in the class 4 pasture was 61 pounds per unit of vegetation. Environmental conditions at these stations were less favorable to growth than those at Hays and Ness City in both 1939 and 1940. When the drought was finally broken in 1941, the cover increased rapidly and plant production per unit of cover was relatively high.

The basal area of sand dropseed is not considered in this comparison of cover and yield since this grass did not occur regularly, and especially because yield of this mid grass per unit of basal cover is usually several times that of either of the short grasses.

s This prairie was mowed annually except during the worst years of drought. Being unfenced, it was subjected to some grazing during winter.
TABLE 3. Percentage basal cover of short grasses, seasonal yields in pounds, and yields in pounds per one percent of cover.

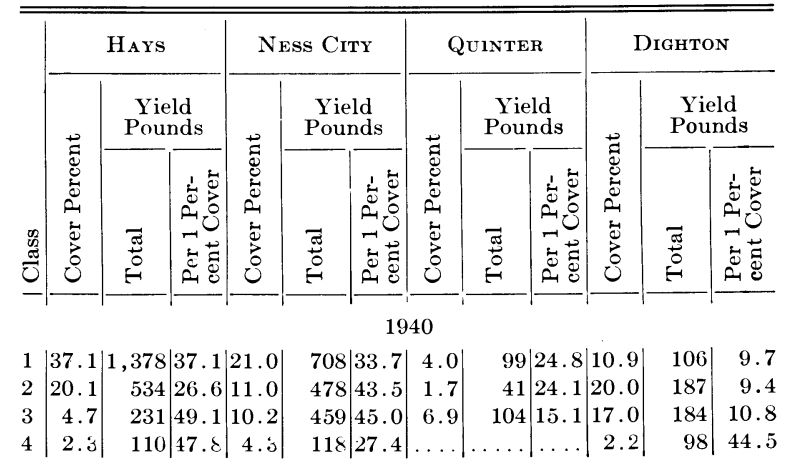

1941

\begin{tabular}{l|l|l|l|l|l|l|l|l|l|l|l|l|l|l|l|l|l|l|l|l|}
9 & 95.6 & 1,524 & 15.9 & 45.0 & 1,390 & 30.9 & 23.7 & 1,081 & 45.6 & 55.3 & 1,854 & 33.5
\end{tabular} \begin{tabular}{l|l|r|r|r|r|r|r|r|r|r|r|r|r|r|}
2 & 42.8 & 902 & 21.7 & 42.6 & 1,610 & 37.8 & 18.5 & 686 & 37.1 & 72.9 & 2,412 & 33.1
\end{tabular}

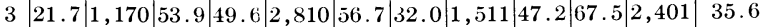
\begin{tabular}{l|l|l|l|l|r|r|r|r|r|r|r|r|}
4 & 22.6 & 1,092 & $48 . \dot{5}$ & 22.0 & $75<$ & 34.2 & $\ldots$ & $\ldots$ & $\ldots$ & 3.4 & 360 & 105.9 \\
\hline
\end{tabular}

The experimental data show the general trends in regard to the effects of drought, dust, and intensity of grazing on cover and yield. Where disturbance has been so widespread and the climatic conditions so erratic, certainly the more uniform results often obtained from a type of grassland of limited range and uniform past history and environment are not to be expected. It is believed, however, that this sampling of a number of apparently similar but widely separated pastures gives a better indication of the prevailing amount and development of the regional vegetation than could be had by more intensive studies on a single range.

A comparison of yields with those of similar vegetation under predrought precipitation is pertinent. Shantz (1911), working in eastern Colorado, calculated the yield of short-grass land from square yard areas. Late in August, 1909, it was 116 pounds per acre from ordinary cover and 400 pounds from an exceptionally thick one. Weaver (1924) secured the average air-dry weight of buffalo grass from a series of quadrats at Burlington, Colorado, and Phillipsburg, Kansas, during three growing seasons. In 1920 , it was 874 and 2,587 pounds per acre at the two stations, respectively; in $1921,1,846$ and 2,373 ; and in 1922, 1,597 and 2,319 pounds in the same order. The data show that the yield is variable even during a series of good years. The amount of available soil moisture gives the explanation of the cause of the differences at the two stations and from year to year. Soil moisture was greater in amount and less often nonavailable for growth at the Kansas station.

In semiarid climates and especially during drought, amount and distribution of rainfall varies widely. Of no less importance is the manner in which rain falls and the cover and condition of the soil. A light rain on a soil with good cover may yield a greater water supply than a heavy one on bare or dust-covered land (Duley 1939; Du!ey \& Kelly 1939). 
In true prairie it has been shown that rainfall is absorbed approximately three times as fast where there is a stabilized cover of prairie grasses (Weaver 1942; Weaver \& Albertson 1943).

Previous experience with drought and previous grazing treatments profoundly affect the vigor and future behavior of short grasses as does also a period of protection. The latter may have been furnished by partial burial by dust. It has been noted that a year of great vegetative activity of buffalo grass, as expressed in abundant stolon production, may be followed by one with much less vegetative increase. Nor is abundant tiller production compatible with the greatest yield of seed in blue grama.

Often the water, light, and nitrogen relations of the grasses were greatly affected by the growth of weeds. A survey of yield of weeds shows, however, that they occurred in large amounts $(1,045$ to 2,277 pounds) in all grades of pastures in 1940 . Exceptions where they were fewer were class 1 and 2 pastures at Hays, class 2 at Dighton, and class 4 at Quinter. In 1941 weeds were again very abundant and nearly always occurred in larger amounts than in 1940 in 9 of the 16 pastures. They averaged far more abundant both years in class 4 pastures than elsewhere. Weeds, however, were not altogether harmful since upon their death they formed a mulch which protected the soil from violent impact of water. The growth and decay of their roots made compacied soil more porous and thus aided infiltration and indirectly promoted growth of perennial grasses.

\section{MONTHLY YIELD OF NATIVE GRASSES}

Previous observations and experiments had shown clearly that the growth and yield of the native grasses varied greatly not only from season to season but also from month to month (Weaver \& Albertson 1943). Therefore an experimental study was made on monthly yields to ascertain variations in the amount and the causes of the fluctuations. Quadrats were clipped in each of the four classes of pastures at the four stations.

The quadrats were marked out in the spring of 1940. Ten were staked in each exclosure where the preceding quadrats were located. The yield was obtained at the end of each month from May to August, inclusive. Short grass, mid grass, and weeds were air-dried and weighed separately and the yields expressed in pounds per acre. Monthly precipitation at each station during the growing season is shown in Figure 7, and available soil moisture at Hays and Dighton in Figures 9 and 10. It should be emphasized that the extended drought in the fall of 1939 weakened the perennial grasses to such a degree that growth was resumed very late in 1940 . Hence, the only vegetation harvested in May was the crop of annual weeds, mostly Lepidium densiflorum, Lappula occidentalis, Monolepis nuttalliana, and Hordeum pusillum.

The total monthly yields of perennial grasses and, in certain pastures, the monthly yields of short grasses are shown by means of graphs in Figure 23. At Hays the total grass produced during June, 1940 on the class 1 pasture was 416 pounds. During July production decreased to 366 pounds but increased to 596 during August. The yield in 1941 was in reverse order. The greatest amount, 750 pounds, was harvested at the end of May when the buffalo grass was heavily laden with seed. The staminate flowers extended a few inches above the semidecumbent leaves, and produced a characteristic spotted appearance of the landscape so common when this grass is in full bloom. Yield decreased to 431 pounds in June and to 95 in July. That of August was only 86 pounds.

Yields in the class 2 pasture followed somewhat the same trends as the preceding but were signifi-
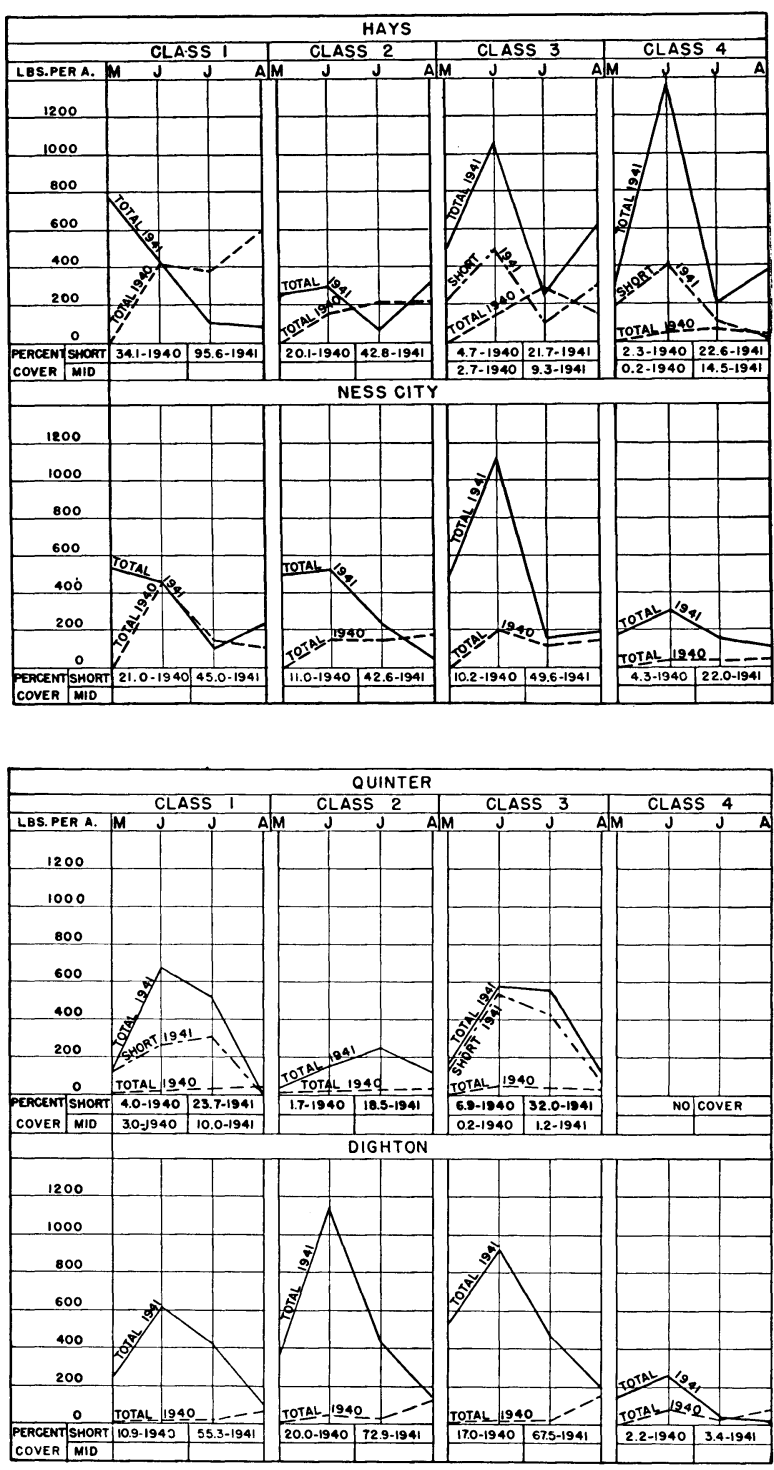

Fig. 23. Yields in May, June, July, and August in different classes of pastures in 1940 and 1941 at each of the four stations. The percentage of basal cover of short grasses and mid grasses is also given for each pasture. 
cantly lower. The short grasses were so badly damaged by drought and competition with little barley both seasons that the yields were low. The total grass produced during June, 1940 was 150 pounds. Yield increased to 185 pounds in July, and to 199 in August. In 1941 competition with little barley was intense during late spring and the yield in May was only 240 pounds. It was slightly greater, 290 pounds, in June. Drought during July reduced the yield to only 55 pounds but in August it was 265 .

Total yield in 1940 on the badly dusted and heavily grazed class 3 pasture, with a cover of only 7.4 percent, increased from zero in May to 306 pounds in July. In August it was only 146 pounds. The low yield in 1940 resulted from feeble growth of the drought-stricken vegetation. Excellent growing conditions in the spring of 1941 resulted in vigorous growth of both short and mid grasses. The shortgrass yield in May was 221 pounds but this increased to 519 in June. The July harvest yielded only 113 pounds. This low yield, however, was offset by one of 318 pounds in the wet month of August. The difference between the short-grass yield and the total yield represents the production of mid grasses, mostly Sporobolus cryptandrus. During May the yield of mid grass was 262 pounds and in June and July 531 and 143 pounds, respectively. The yield in August was 290 pounds. Rapid recovery of the vegetation of this and other badly damaged areas was probably due to accumulation of fertile soil from dusting, and semi-dormancy through much of the drought period.

Total yield of grasses in class 4 pasture in 1940 was much less than that in class 3 . The total amount of short and mid grasses produced in June was only 22 pounds. In July it was 59 pounds and in August 51. The cover of short grass increased to 22.6 percent in 1941 and the yield in May was 192 pounds. Production increased to 426 pounds in June and then declined to 97 and 38 pounds, respectively, in July and August. The mid grass grew vigorously in 1941 and in fall had a basal cover of 14.5 percent. The yield in May was only 78 pounds. In June, however, it reached a value of 959 pounds which, with the short grass, exceeded the yield of all the higher classes of pastures (Fig. 23). A yield of only 98 pounds in July resulted from a drought of short duration; in August, it was 320 pounds.

Yield at Ness City in 1940 was relatively high in June in class 1 pasture but low thereafter. It was uniformly low in the other three classes (Fig. 23). Extremely low yields were produced in all pastures at Quinter in 1940, since the vegetation was sparse and had scarcely recovered from the extremely severe drought of the previous fall. There was some yield at the end of May, 1941, good yields in pasture classes 1 and 3 in June and July, but they were low following the August drought. At Dighton in 1940, low monthly yields were secured, with an increase in growth in August. Conversely, the yields even in May, 1941, were good at all stations and those of June were excellent. Thev were obtained from a vigorous, rapidly increasing cover, with the exception of class 4 pasture.

\section{Discussion}

Variability in productivity was due in part to uneven distribution of precipitation but also to the previous experience of the vegetation especially as regards drought, dusting, and intensity of grazing. The very low yields at the two westerly stations, Quinter and Dighton, in 1940 are attributed to two factors - the extremely severe drought that prevailed there during the preceding fall and winter and the low precipitation and small amount of available water in 1940. Rainfall in the spring at these stations was lower than at the others (except Havs in May) and did not promote much growth (Fig. 7). Low precipitation would account for the depressed yield in June and July, but the vegetation at neither station responded favorably to the 2.5 to 4 inches of rainfall and good water content of soil during August (Figs. 7 and 10). The late resumption of growth in 1940 at Hays and Ness City was also an after-effect of the fall drought of the preceding year. The greater yield at Hays in class 1 pasture than in the others is explained on the basis of a more rapidly extending and more vigorous cover. While this denser vegetation was undoubtedly exhausting available soil moisture more rapidly than the more scattered plants in the other pastures, the very presence of the cover greatly promoted water infiltration and thus compensated this loss. Moreover, there were more early growing, water dissipating, annual weeds where the perennial grasses were sparse.

In 1941 the heaviest monthly yields occurred in May in class 1 pastures at Hays and Ness City but a month later in the other class 1 pastures. Precipitation was somewhat higher at Hays and Ness City (Fig. 7) and the soil at Hays had much more water available for growth than that at Dighton (Figs. 9 and 10 ). Moreover, the vegetation seemed much more vigorous at the stations where growth was earlier. Decrease in monthly productivity after the high early yields was undoubtedly due in part to continuous clipping (Weaver \& Hougen, 1939). A very dry July followed by a wet August at Hays accounts for the upward trend of the graph of production at this station. From the excellent yield in class 3 and 4 pastures it would seem that dusting stimulated growth under good precipitation, also in both pastures highyielding mid grasses were present. The same effect is evident in class 3 pasture at Ness City where mid grasses were not found. Growth in the several pastures at Quinter showed rather uniform monthly trends. Less than an inch of rainfall in August resulted in little development in late summer. At Dighton the yields in all pastures directly reflect the rainfall of June, July, and August which was about $5,4.5$, and 2 inches, respectively. Decrease in monthly productivity was similar in pastures with only 3 percent basal cover to those with 55 to 73 percent. Here weeds grew in numbers and stature somewhat in inverse proportion to the amount of perennial grasses. 
Blue grama and buffalo grass have a remarkable capacity, except immediately after extremely severe and prolonged drought, to revive quickly and grow rapidly at any time during the warm season and to become dormant but remain alive when available soil moisture is exhausted. This is in accord with their semiarid environment and normally occurs every year. During a drought year it may take place several times. But when the spark of life is nearly extinguished, as in 1939, recovery is slow. The difference between total denudation and relict vegetation over thousands of square miles depended upon the wonderful drought resistance of these two species. They remained where all other perennial vegetation vanished. Sand dropseed, also very drought resistant and likewise with remarkable powers of recuperation, has spread widely on the bare, dry, warm soils in the past five years.

Revegetation of the central Great Plains area depends in the main upon the growth and spread of these xeric but nutritious grasses. These data show clearly their ability, once established, to increase their area. Buffalo grass alone can spread with great rapidity. Blue grama and sand dropseed increase much more slowly and must have good years for seed production followed by favorable years for seedling establishment (Weaver \& Mueller 1942). Although the cover may increase fourfold in a single year, which is an unusual gain, on the thousands of ranges where it was only 2 to 5 percent (Weaver \& Albertson 1940a) this process must be repeated several times before the cover is completely restored. A series of good years are necessary for restoration of a plant matrix as dense as that which prevailed before the drought. It will not occur quickly. Succession even in subseres proceeds slowly and weeds will play their inevitable and important part (Clements 1916, 1929). The more serious the degeneration the longer will be the period of redevelopment. Upon the revegetation of the range depends the fundamental economy of the Great Plains (Clements \& Chaney 1937). Retardation of recovery by injudicious grazing must be carefully avoided; cropping practices must be such as to stabilize plowed land and prevent soil from being carried away as dust; and the best principles of ecological and agronomic practices must be used in reclothing marginal lands with grass and restoring a normal cover to depleted ranges (Savage 1939; Savage \& Runyon 1937).

\section{EFFECTS OF DIFFERENT INTENSITIES OF CLIPPING ON YIELD}

An understanding of the relationship of plant productivity to intensity of grazing is very important. In order to secure information on this phase of range conservation as applied to short grasses, selected areas were clipped at different intervals and the vields determined. The experiments were done at all four stations, four classes of pastures being used at each station. In each of the 16 pastures, the four areas used were closely adjacent and had received the same treatment as regards the amount of grazing, severity of drought, and deposition of dust previous to 1940 , when the study was begun. A total of nearly 40 meter quadrats was employed in each pasture, approximately 10 under each of the four different treatments. The intensity of clipping for each of the four treatments was as follows:

1. Clipped monthly from May to August, inclusive, in 1940 and 1941.

2. Clipped monthly as above in 1940, but clipping deferred until the end of the season in 1941.

3. Unclipped in 1940; clipped monthly in 1941.

4. Unclipped in 1940; clipping deferred until the end of the season in 1941.

The area of the basal cover in the fall of 1941, when the quadrats were charted, was approximately the same under treatments 1 and 2 . It was likewise practically the same under treatments 3 and 4 . The basal cover of short grass and mid grass is given, therefore, as the average of conditions 1 and 2 , and 3 and 4 in each class of pasture, respectively (Fig. 24). It is significant, however, that the total cover ranged from 2 to 4 percent greater under treatments 3 and 4.

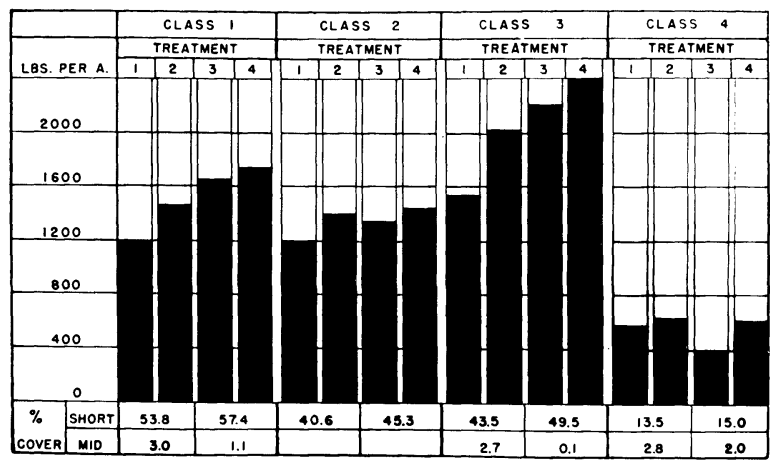

Fig. 24. Average basal cover and yield in pounds per acre in 1941 of short grass in each class of pasture when clipped monthly in 1940 and 1941 (treatment 1), when elipped monthly in 1940 but only in fall in 1941 (treatment 2), when unclipped in 1940 but clipped monthly in 1941 (treatment 3 ), and when unclipped until the fall of 1941 (treatment 4).

Yield of short grasses, with one exception, was greatest under treatment 4 and least under 1 (Fig. 24). This indicates that close elipping of short grass for two seasons tended to reduce the yield and that each of the other treatments were, in order, nearly always less detrimental. In class 1 pastures for example, the average yield of short grass was 1,182 pounds per acre. Under treatment 2 it was 1,463 pounds or nearly 300 pounds per acre greater than under monthly clipping. Under treatment 3 the yield was further increased to 1,624 pounds. The greatest yield was 1,681 pounds per acre in the pasture which had two years of rest (treatment 4 ). The yield of class 2 pastures was somewhat less than that of class 1 , but, with one minor exception, it varied in the same sequence. Under treatments 1 to 4 yields were 
$1,203,1,400,1,390$, and 1,470 pounds per acre, respectively.

Yields of class 3 pastures consistently increased from treatments 1 to 4 . They were also greater for each treatment than the corresponding yield in classes 1 and 2 . Under treatment 1 , the production of short grass was 1,560 pounds per acre. It was 2,042 pounds under treatment 2, and 2,284 and 2,400, respectively, under treatments 3 and 4.

The short grass in class 4 pastures was doubtless affected less by intensity of clipping than by competition of annual weeds. Yields were therefore not consistent. From treatments 1 to 4 , in order, they were $575,624,370$, and 593 pounds per acre.

The yield of mid grasses, mostly Sporobolus cryptandrus, was always greater under the second treatment than the first, and usually greater under the fourth than the third. This indicates that monthly clipping greatly reduced growth and yield. The presence of sand dropseed usually indicated a broken cover in the original short grass. Its rate of growth varied greatly. For example, in the class 3 pastures, the yield varied from 0 to 400 pounds per acre in 1941 .

The effect of intensity of clipping upon the monthly and seasonal yield in 1941 in representative class 1 and class 3 pastures is given in Table 4 . The vield of short grass in the class 1 pasture under the first treatment was 1,362 pounds per acre. Under treatments 2,3 , and 4 it was $1,524,1,976$, and 2,185 pounds per acre, respectively. The monthly yield for the same year was significantly greater under treatment 3 than under 1. In May it was 1,216 pounds per acre as compared with 750 pounds under treatment 1 . In the same sequence, it was 462 and 431 pounds in June, 167 and 95 in July, and 129 and 86 in August. Under both treatments, the yields were greatest in May and gradually decreased thereafter.

TABLE 4. Yields in pounds per acre of short grasses in 1941 in representative class 1 and class 3 pastures under different intensities of clipping.

\begin{tabular}{|c|c|c|c|c|c|c|c|}
\hline \multirow{2}{*}{ Station } & \multirow{2}{*}{ Class } & \multirow{2}{*}{$\begin{array}{l}\text { Treat- } \\
\text { ment }\end{array}$} & \multicolumn{5}{|c|}{ Yields By Months } \\
\hline & & & May & June & July & August & Total \\
\hline \multirow{4}{*}{ Hays.... } & \multirow{4}{*}{1} & 1 & 750 & 431 & 95 & 86 & 1,362 \\
\hline & & 2 & & 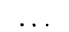 & 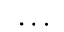 & $1, \tilde{524}$ & 1,524 \\
\hline & & 3 & 1,216 & 462 & 167 & 129 & 1,976 \\
\hline & & 4 & $\ldots$ & $\ldots$ & $\ldots$ & 2,185 & 2,185 \\
\hline \multirow{4}{*}{ Quinter. } & \multirow{4}{*}{3} & 1 & 147 & 542 & 473 & 73 & 1,235 \\
\hline & & 2 & $\ldots$ & & 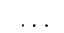 & 1,511 & 1,511 \\
\hline & & 3 & 125 & 596 & 697 & 200 & 1,620 \\
\hline & & 4 & $\ldots \ldots$ & $\ldots$ & $\ldots$ & 1,947 & 1,947 \\
\hline
\end{tabular}

The seasonal yield in class 3 pasture under treatment 1 was 1,235 pounds (Table 4). Under succeeding treatments it increased to $1,511,1,620$, and 1,947 pounds, respectively. Moreover, the yield, as in the class 1 pasture, was greater each month, except May, in the pastures under the third treatmont than under the first. The lower yield in May may be attributed to less cover here than in the class 1 pasture in spring, since the increase in cover was extremely rapid. The dry August limited the yield of short grasses to 73 pounds under the first treatment but 200 under the third.

\section{Discussion}

Grazing, or clipping to simulate grazing, is a more or less destructive process since it removes much of the photosynthetic area from the plant. Preservation of pasture grasses depends upon manufacture and storage of foods by the plants in excess of those consumed in growth. Whenever grazing is so intensive that it permits complete and frequent removal of the green shoots it greatly reduces the manufacture of carbohydrates and prevents their storage in underground parts. Such abrupt decrease in photosynthetic activity causes a corresponding decrease in the growth of roots. Continued defoliation is extremely injurious and unless reasonable precautions are taken to prevent it the effects are likely to become cumulative and cause serious deterioration of pasture or range. This may be followed by erosion, loss of nutrients, and general impoverishment of the soil.

Canfield (1939) found that quadrats of black grama (Bouteloua eriopoda) clipped periodically during the growing season to a height of one inch made substantial gains in tuft areas the first year, one of unusually favorable growth, but these gains were temporary. Losses in the second and third year were greater than these gains, and losses continued to the end of the experiment. Similar results were obtained where the clipping was 2 inches high.

Results from studies on the effects of the removal of the photosynthetic area are in agreement that the yield and vigor of the vegetation vary inversely with the frequency of clipping. Aldous (1930) applied clipping treatments at two-week intervals to prairie grasses (chiefly big and little bluestems) at Manhattan, Kansas. He found that the density of the vegetation decreased about 60 percent in three seasons. Clipping at three-week intervals resulted in only 13 percent reduction. Disappearance of valuable species was proportional to frequency of cutting. The higher nutritive value of the forage gained from frequent harvesting did not compensate the loss in yield.

Total yields of quadrats clipped at frequent intervals at Lincoln, Nebraska, exceeded the single yield of the control of Andropogon scoparius by 11 and 26 percent during two seasons, respectively. Similar yields of Bouteloua gracilis on upland were 6 percent greater than the control and 30 percent greater on lowland. Poa pratensis when frequently clipped exceeded the control in yield by 5 percent. This increased growth is made at the expense of accumulated reserves in the roots and crown. The first growth following defoliation is largely "transfer growth" from storage tissue to herbage. It results in decreasing the vigor of the plant. Thus, the greater frequency of removing the top either by clipping or grazing at first results in greater yield of dry matter, but on'y unt:1 a point is reached where 
the defoliation is so frequent as to prevent the rebuilding of root reserves.

Quadrats frequently clipped during a second season always gave lower yields than a single clipping of the controls. In little bluestem the yield averaged 46 and 49 percent less, in big bluestem 28 percent, and in mixed little and big bluestem 43 and 53 percent less than the control. Yields of quadrats frequently clipped during two years were likewise much lower than those similarly elipped for only a s.ngle year. In little bluestem, the former yielded 60 percent less, in big bluestem 37, and in mixed bluestems 51 percent. Yields were still further reduced where clipping was continued a third season. Compared with controls they were 56 to 68 percent less, respectively, in little bluestem and mixed-bluestem types. Moreover, when these yields were compared with those from quadrats frequently clipped for two years, they were found to be 42 and 23 perecnt less, respectively (Weaver \& Hougen 1939). Thus, there is a rapid decrease in yield following too close utilization of a pasture.

McCarty (1938) has shown that the "initial growth of herbage in spring is made at the expense of the carbohydrate accumulations stored in the basal organs during the preceding season. Concentration of carbohydrates in both herbage and basal organs of the plant is inversely related to the rate of herbage growth. This relationship is maintained throughout the entire annual cycle of growth. The accumulation of carbohydrates stores is delayed, therefore, until most of the annual herbage growth is produced." It is well known that all of the stored food is not ordinarily used in normal early growth of perennial grasses. But if the new growth is removed by early grazing or elipping there results a diminution in the reserve food: a second close elipping may further deplete the supply. Thus, the progressive increase in yield of the closely clipped quadrats and the final death of many plants may be readily understood. Mixed prairie, for example, in past decades has lost much in its forage production in being reduced to the short grass disclimax. Where upland, little bluestem degenerated into pasture of the short-grass type at Lincoln, Nebraska, the seasonal yield was reduced about half.

Biswell and Weaver (1933) found not only that the total dry weight produced from sods frequently clipped after transplanting ranged from 13 to 47 percent of that of the same species of prairie grass unclipped after transplanting but also that the clipped plants failed to produce new rhizomes and many of the old ones died. The length of the roots was greatly decreased, and the relative production of roots was more greatly reduced than that of tops. Plants weakened by repeated clipping renewed growth slowly if at all after the sods were frozen, although the controls made an excellent development. They give a comprehensive rev'ew of the literature.

Robertson (1933) has shown the very detrimental effects of removing the tops of seedling grasses upon the growth of both tops and roots.
The farmer's experience in recent times has made him well aware of the importance of good pastures for feed during severe drought, for preventing damage from wind erosion, and for combatting damage by floods which often follow prolonged drought. A great problem lies in adjusting livestock to the carrying capacity of the range. The false creed that profits depend on livestock numbers must be replaced by the viewpoint that native vegetation is a perennial crop and that next year's yields may be lessened somewhat in proportion to the extent of this year's grazing and trampling. It is only slowly being realized that larger immediate returns, to say nothing of future yields, from the midwestern ranges can be obtained from moderate stocking than from overgrazing. Man has under his control the season of grazing, the frequency of removal of the new growth of grasses, and how elosely they are grazed. While he cannot prevent droughts he can keep the ranges in good condition to endure them.

\section{SUMMARY}

The very extensive range lands of western Kansas are now recovering from the extremely damaging effects of drought and burial under dust. Those that were most judiciously grazed before and during the dry eycle and best protected from dust accumulation, either by large size or by stabilizing nearby tilled land, usually suffered the least degeneration.

At four widely separated stations, Hays, Ness City, Dighton, and Quinter, pastures were selected for study at the end of the most severe drought ever recorded. Four classes of pastures were investigated at each station where the range use was known or where records were obtained. Class 1 had been lightly grazed and lightly dusted, class 2 heavily grazed and lightly dusted, class 3 lightly grazed but heavily dusted, and class 4 both heavily grazed and heavily dusted. A prairie at Phillipsburg had degenerated like the preceding to short grass but on'y because of drought.

A record of annual and monthly precipitation was obtained for each station, available soil water to 5 feet in depth was ascertained monthly during the growing season, and other environmental factors were studied in 1939, 1940, and 1941.

Increase in basal area of perennial grasses, amount of the various species concerned, and dry weight of forage produced were the chief criteria used in measuring recovery. Exclosures against stock were made. In each exclosure 20 meter quadrats were elipped annually and the basal area of the perennial grasses charted by means of a pantograph in 1940 and 1941. Blue grama (Bouteloua gracilis) and buffalo grass (Buchloe dactyloides), both short grasses, composed the bulk of the scanty, relict perennial vegetation. Sand dropseed (Sporobolus cryptandrus), which occurred irregularly and sparingly, was practically the only mid grass. Native forbs were so few as to be almost negligible but annual weeds were abundant. Increase or decrease of 
basal area of each species of grass was ascertained, and the separate yields of short grasses, mid grasses, and weeds were obtained.

Low precipitation in 1939, 7 to 10 inches below the normal 19 to 23 inches, and extremely dry fall further reduced the much depleted plant cover. Drought also weakened the vegetation so greatly that it remained almost dormant at all stations the following spring, and nearly throughout the summer at Dighton and Quinter.

The growing season of 1940 showed much improvement over that of 1939 , but precipitation was below normal at all stations during April and June. At Hays and Ness City only was the amount of precipitation normal. Despite the moderate rainfall, the thoroughly dried soil was often without available water at all stations and growth was not continuous nor yields high, except those of annual weeds.

In 1941 the rainfall was above normal more than half of the time from April to September. The soil was wet from early spring until July; periods without rain were not prolonged and not severe, and the drought was definitely broken.

Basal area, first determined in the fall of 1940 after a year of recovery, showed that the cover was invariably least in all class 4 pastures at any station, and nearly always highest in class 1 . Cover in pasture classes 2 and 3 was intermediate, but often higher in the lightly grazed but heavily dusted class 3. A light cover of dust often furnished some protection against drought by aiding dormancy. The average basal cover of short grasses in the four class 1 pastures was 18 percent; that in the others in order 13.7, 13.4, and 2.2 percent. During the excellent season for growth in 1941 these pastures extended their basal cover to $56.8,46.3,44.3$, and 17.2 percent, respectively. Thus, classes 1 to 3 on an average tripled their cover; that in class 4 increased nearly eightfold.

Blue grama exceeded buffalo grass in amount of basal area in all but two class 1 and 2 pastures. But at the end of 1941 buffalo grass exceeded blue grama in basal area in 7 of these 8 pastures. There was about 4.5 times as much buffalo grass as blue grama in the average of class 1 pastures, and about 3 times as much in the average of class 2 . In the heavily dusted pastures (classes 3 and 4) in 1940, buffalo grass ranked somewhat higher in all except 2, but percentage of cover was low. In 1941, so great were its gains, it ranked far ahead of blue grama, often being 3 to 5 times as abundant. In the few pastures where sand dropseed occurred it increased rapidly but seldom composed more than a small part of the vegetation. Despite fourfold increases of cover in low grade pastures, several good years for seed production and growth of seedlings will be required for complete restoration of the cover.

Only broad correlations were found between amount of basal cover and yield, the drought-stricken vegetation varied greatly in vigor; the amount of dust accumulation resulted in varying degrees of dor- mancy and protection from drought. Moreover, occurrence and amount of soil moisture available to growth was extremely variable.

During 1941 an abundance of water greatly invigorated the weakened short grasses at Hays and Ness City. But where increases of the moderately small cover in the best pastures had been high in 1940 , seasonal yield in relation to amount of cover was less in 1941. The decrease was from 27-44 pounds per acre for 1 percent basal cover in 1940 to $16-38$ pounds in 1941. But where dusting had been heavy and the original cover very open at these stations, production per unit of basal cover increased in 1941, often greatly.

At Quinter and Dighton conditions were unfavorable to growth in 1940 and yield per unit of cover was low, 10 to 25 pounds per 1 percent of cover per acre. It increased, with one exception, 21 to 32 pounds per unit cover in 1941 over that in 1940 . Where the initial cover was least (about 2 percent) and dusting greatest (class 4 pastures) the yield was even more greatly increased.

Cover of sand dropseed is not included in preceding statements of yields since its yield per unit of cover is usually several times as great as that of short grasses.

These short-grass yields were mostly far below those made at Phillipsburg during the years of more nearly normal precipitation, 1920, 1921, and 1922. Only in one pasture at Ness City and at Dighton where the basal cover was about 70 percent was this average yield, 2,400 pounds per acre, attained even during the wet year, 1941.

In many pastures both spread and yield of the perennial grasses were greatly reduced by an abundance of weeds, chiefly Hordeum pusillum, Lepidium densiflorum, Chenopodium album, and Salsola pestifer. They absorbed much water, and greatly reduced the light both when living and dead. They were most abundant in class 4 pastures. Weeds usually yielded one-fourth ton to more than one ton per acre.

Monthly yields were obtained from a series of 10 quadrats in each of four classes of pastures at the four stations. Great variability in monthly yield resulted from uneven distribution of precipitation and previous experience of the vegetation as regards drought, dusting, and intensity of grazing.

Yields in 1940 were extremely low at Quinter and Dighton where previous drought had been most severe. At Hays and Ness City there was no yield in any pasture in May, but moderate yields each summer month thereafter, except in class 4 pastures.

The highest or next to the highest monthly yields in 1941 occurred in May in class 1 and 2 pastures at Hays and Ness City, but after May or June yields decreased sharply. But in class 3 and 4 pastures they were the greatest in June, the June yield usually far exceeding that in the class 1 and 2 pastures. Excellent yields from a rapidly increasing cover occurred in 1941 at Quinter and Dighton where they were high in May but highest in June, and low 
following the August drought. Early growing, water dissipating, annual weeds often reduced the May yield of perennial grasses.

In order to determine the effects of different intensities of clipping on yield, grasses were (1) clipped monthly in 1940 and 1941, (2) elipped monthly in 1940 but only in fall in 1941, (3) unclipped in 1940 but clipped monthly in 1941, and (4) unclipped until the fall of 1941 . These 4 treatments were applied in class 1 to 4 pastures at both Hays and Quinter. The cover was approximately the same in the fall of 1941 under treatments 1 and 2, but 2 to 4 percent higher, although similar under treatments 3 and 4 .

In class 1 pastures the average yield of short grass was 1,182 pounds per acre under treatment 1 ; under treatments 2 to 4 it was $1,463,1,624$, and 1,681 pounds, respectively. A sequence of increasing yields was also obtained in class 2 and 3 pastures, the class 3 pasture giving greater yields under each treatment than pasture classes 1 and 2 . In class 4 pastures the short grasses were affected less by intensities of clipping than by competition of weeds.

\section{LITERATURE CITED}

Albertson, F. W. 1937. Ecology of mixed prairie in west central Kansas. Ecol. Monog. 7: 481-547.

1938. Prairie studies in west central Kansas. Kan. Acad. Sei. Trans. 41: 77-83.

1939. Prairie studies in west central Kansas. Kan. Acad. Sci. Trans. 42: 97-107.

1941. Prairie studies in west central Kansas. Kan. Acarl. Sci. Trans. $44: 48-57$.

Albertson, F. W., \& J. E. Weaver. 1942. History of the native vegetation of western Kansas during seven years of continuous drought. Ecol. Monog. 12: 23-51.

Aldous, A. E. 1930. Effect of different clipping treatments on the yield and vigor of prairie grass vegetation. Ecology 11: 752-759.

Biswell, H. H., \& J. E. Weaver. 1933. Effect of frequent clipping on the development of roots and tops of grasses in prairie sod. Eeology 14: 368-390.

Canfield, R. H. 1939. The effect of intensity and frequency of clipping on density and yield of black grama and tobosa grass. U. S. Dept. Agr. Tech. Bul. 681.

Clements, F. E. 1916. Plant succession. Carnegie Inst. Wash. Pub. 242.

1929. Climatic eycles and changes of vegetation. Rept. Conf. Cycles Carnegie Inst. Wash. 3=4 : 64-71.

Clements, F. E., \& R. W. Chaney. 1937. Environment and life in the Great Plains. Carnegie Inst. Wash. Suppl. Pub. 24.

Culley, M. J., R. S. Campbell, \& R. H. Canfield. 1933. Values and limitations of clipped quadrats. Ecology 14: $35-39$.

Donald, C. M. 1941. Pastures and pasture research. Six lectures delivered at the University of Sydney, 1941. Univ. Sydney.

Duley, F. L. 1939. Surface factors affecting the rate of intake of water by soils. Soil Sci. Soc. Amer. Proc. $4: 60-64$.

Duley, F. L., \& L. L. Kelly. 1939. Effect of soil type, slope, and surface conditions on intake of water. Neb. Agr. Col. Exp. Sta. Res. Bul. 112.
Hanson, H. C. 1938. Ecology of grassland. Bot. Rev. 4: $51-82$.

Hein, M. A., \& P. R. Henson. 1942. Comparison of the effect of clipping and grazing treatments on the botanical composition of permanent pasture mixtures. Jour. Amer. Soc. Agron. 34: 566-573.

McCarty, E. C. 1938. The relation of growth to the varying carbohydrate content in mountain brome. U. S. Dept. Agr. Tech. Bul. 598.

Mueller, I. M., \& J. E. Weaver. 1942. Relative drought resistance of seedlings of dominant prairie grasses. Ecology 23: 387-398.

Robertson, J. H. 1933. Effect of frequent clipping on the development of certain grass seedlings. Plant Physiol. 8: 425-447.

Sampson, A. W. 1914. Natural revegetation of range lands based upon growth requirements and life history of the vegetation. Jour. Agr. Res. 3: 93-147.

Sarvis, J. T. 1923. Effects of different systems and intensities of grazing upon the native vegetation at the northern Great Plains field station. U. S. Dept. Agr. Bul. 1170.

Savage, D. A. 1937. Drought survival of native grass species in the central and southern Great Plains, 1935. U. S. Dept. Agr. Tech. Bul. 549.

1939. Grass culture and range improvement in the central and southern Great Plains. U. S. Dept. Agr. Cir. 491.

Savage, D. A., \& H. E. Runyon. 1937. Natural revegetation of abandoned farm land in the central and southern Great Plains. Internatl. Grassland Cong., Aberystwyth, Gt. Brit., Rept. Sec. 1. Grassland Ecology, pp. 178-182.

Shantz, H. L. 1911. Natural vegetation as an indicator of the capabilities of land for crop production in the Great Plains area. U. S. Dept. Agr. Bur. Plant Ind. Bul. 201.

Taylor, W. P., \& J. V. G. Loftfield. 1924. Damage to range grasses by the Zuni prairie dog. U. S. Dept. Agr. Bul. 1227.

Weaver, J. E. 1924. Plant production as a measure of r nvironment. A study in crop ecology. Jour. Ecol. 12: $205-237$.

194. Competition of western wheat grass with relict vegetation of prairie. Amer. Jour. Bot. 29: 366-372.

Weaver, J. E., \& F. W. Albertson. 1936. Effects of the great drought on the prairies of Iowa, Nebraksa, and Kansas. Ecology 17: 567-639.

1940. Deterioration of grassland from stability to denudation with decrease in soil moisture. Bot. Gaz. 101: 598-624.

1940a. Deterioration of midwestern ranges. Ecology 21 : $216-236$.

19.13. - Resurvey of grasses, forbs, and underground plant parts at the end of the great drought. Ecol. Nonog. 13: 63-117.

Weaver, J. E., \& V. H. Hougen. 1939. Effect of fre quent clipping on plant production in prairie and pasture. Amer. Mid. Nat. 21 : 396-414.

Weaver, J. E., \& I. M. Mueller. 1942. Role of seedlings in recovery of midwestern ranges from drought. Ecology 23: 275-294.

West, C., G. E. Briggs, \& F. Kidd. 1920. Methods and significant relations in the quantitative analysis of plant growth. New Phytol. 19: 200-207.

West, 0. 1936. An investigation of the methods of botanical analysis of pasture. South African Jour. Sci. 33 : 501-559. 